\title{
Synthesis and Biological Screening of New Cyano-Substituted Pyrrole Fused (Iso)Quinoline Derivatives
}

\author{
Maria Cristina Al-Matarneh 1,2,*, Roxana-Maria Amărandi 1,3 ${ }^{\mathbb{D}}$, Ionel I. Mangalagiu ${ }^{1}$ (D) and Ramona Danac ${ }^{1, *(\mathbb{D})}$ \\ 1 Department of Chemistry, Faculty of Chemistry, Alexandru Ioan Cuza University of Iași, 11 Carol I, \\ 700506 Iași, Romania; roxana.amarandi@chem.uaic.ro (R.-M.A.); ionelm@uaic.ro (I.I.M.) \\ 2 "Petru Poni" Institute of Macromolecular Chemistry of Romanian Academy, 41A Grigore Ghica Voda Alley, \\ 700487 Iași, Romania \\ 3 TRANSCEND Research Center, Regional Institute of Oncology, 2-4 General Henri Mathias Berthelot Street, \\ 700483 Iasi, Romania \\ * Correspondence: almatarneh.cristina@icmpp.ro (C.M.A.-M.); rdanac@uaic.ro (R.D.)
}

Citation: Al-Matarneh, M.C.;

Amărandi, R.-M.; Mangalagiu, I.I.;

Danac, R. Synthesis and Biological

Screening of New Cyano-Substituted

Pyrrole Fused (Iso)Quinoline

Derivatives. Molecules 2021, 26, 2066.

https://doi.org/10.3390/

molecules 26072066

Academic Editor: Vincenzo Piccialli

Received: 7 March 2021

Accepted: 1 April 2021

Published: 3 April 2021

Publisher's Note: MDPI stays neutral with regard to jurisdictional claims in published maps and institutional affiliations.

Copyright: (c) 2021 by the authors. Licensee MDPI, Basel, Switzerland. This article is an open access article distributed under the terms and conditions of the Creative Commons Attribution (CC BY) license (https:// creativecommons.org/licenses/by/ $4.0 /)$.
Abstract: Several new cyano-substituted derivatives with pyrrolo[1,2-a]quinoline and pyrrolo[2,1a] isoquinoline scaffolds were synthesized by the [3+2] cycloaddition of (iso)quinolinium ylides to fumaronitrile. The cycloimmonium ylides reacted in situ as 1,3-dipoles with fumaronitrile to selectively form distinct final compounds, depending on the structure of the (iso)quinolinium salt. Eleven compounds were evaluated for their anticancer activity against a panel of 60 human cancer cell lines. The most potent compound 9a showed a broad spectrum of antiproliferative activity against cancer cell lines representing leukemia, melanoma and cancer of lung, colon, central nervous system, ovary, kidney, breast and prostate cancer. In vitro assays and molecular docking revealed tubulin interaction properties of compound $9 \mathbf{a}$.

Keywords: $3+2$ cycloaddition; pyrrolo fused (iso)quinoline; anticancer; tubulin polymerization inhibitor; molecular docking

\section{Introduction}

Fused polyazaheterocyclic derivatives are essential structural motifs, being commonly present in natural products and bioactive agents. Due to their wide range of biological activities, they represent one of the most important classes of organic compounds, with extensive applications in medicinal chemistry [1].

Their design, usually based on a combinatorial method having the purpose of assembling different pharmacophores in the same molecular framework, is of considerable interest due to the large variety of such molecules showing promising biological activities. Hybrid drugs are of particular interest since they can potentially eliminate most of the problems encountered with currently used drugs such as toxicity, major side effects and drug resistance [2-4].

Particularly, fused compounds containing quinoline and isoquinoline moieties constitute select classes of compounds, both heterocycles being widely explored for the development of bioactive molecules $[3,5,6]$. Notably, pyrrolo[2,1-a] isoquinoline is a common scaffold in multiple alkaloids (crispines, trolline, lamellarins) having diverse biological action, including antitumor, antibacterial, antifungal and antiviral activities [7-9]. For example, lamellarin D, a natural marine alkaloid, is a topoisomerase I inhibitor that induces apoptosis in several cancer cell lines [8-10], while crispine A is a potent antiproliferative alkaloid [11] (Figure 1). In addition, the pyrrolo[1,2-a]quinoline moiety is present in the natural alkaloid gephyrotoxin, a muscarinic antagonist [12,13], while other pyrrolo[1,2a]quinoline derivatives are known as activators of caspases and inducers of apoptosis by inhibiting tubulin polymerization and effective anticancer agents (Figure 1) [14,15]. 


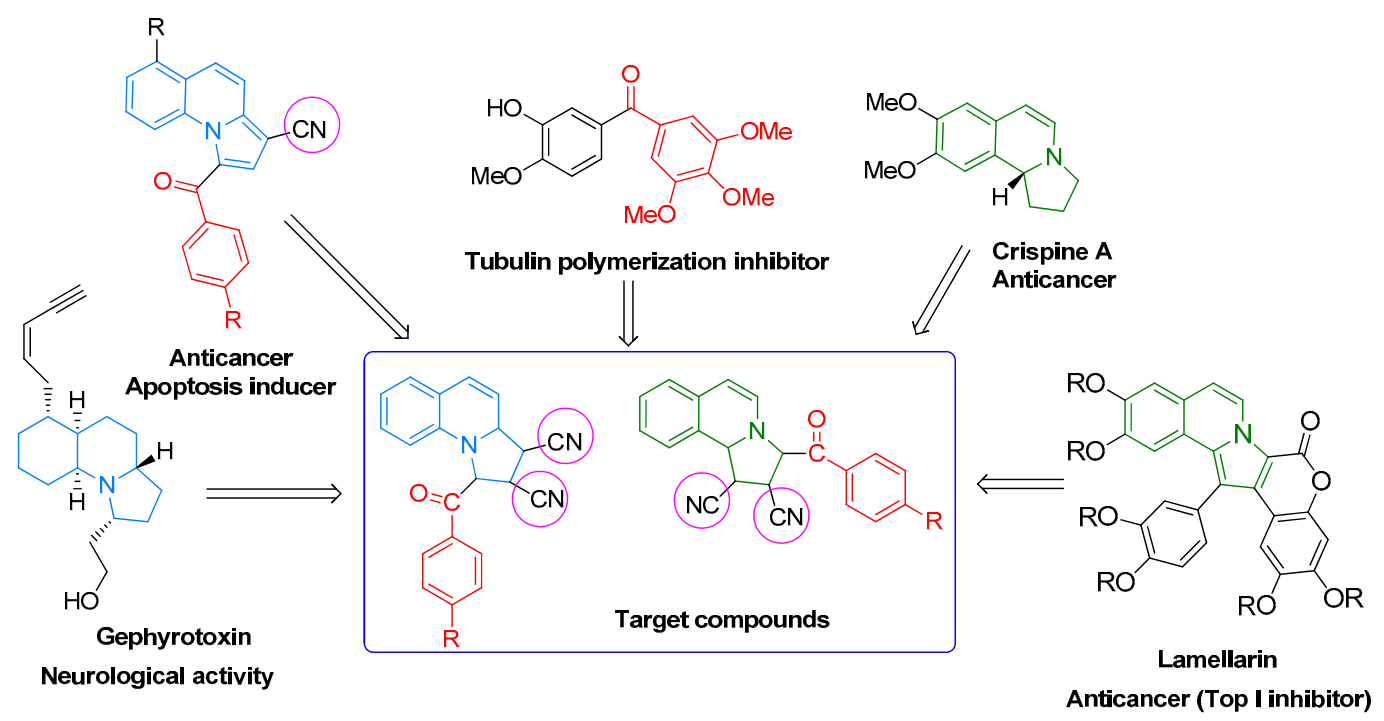

Figure 1. Design in the class of cyano-substituted pyrrolo(iso)quinolines.

Considering the biological relevance of these two important scaffolds and the positive tendency for their further development, pyrrolo(iso)quinoline derivatives have increasingly become targets of interest in the organic synthetic community. Over the past decades, several synthetic methodologies to generate compounds with pyrrolo[2,1-a]isoquinoline or pyrrolo[1,2-a]quinoline cores have been developed, including the [3+2] cycloaddition of the corresponding cycloimmonium ylides to various dipolarophiles, cyclization of lactam derivatives, intramolecular cyclizations, as well as several transition metal catalyzed C-C and $\mathrm{C}-\mathrm{N}$ bond formation reactions $[3,6,16]$. It is worth mentioning that the nature and the position of the substituents in the core-containing compounds define their biological profile.

Taking into account the abovementioned details, as well as our ongoing interest in developing new bioactive fused heterocycles [17-22], we present herein the design and synthesis of novel pyrrolo[1,2-a]quinoline and pyrrolo[2,1-a]isoquinoline derivatives which show great promise as anticancer agents. The compounds bear cyano- and 4-substituted phenacyl groups as substituents at the pyrrole ring. The choice of the substituents was based on the observation that both cyano and 4-substituted benzoyl groups were found to be important for the anticancer activity of various bioactive molecules [14,15,23] (Figure 1). The new compounds were evaluated for their anticancer activity by screening against a panel of 60 human tumor cell lines. Moreover, tubulin polymerization assays and molecular docking studies were carried out in order to gain some insights into the mode of action of the tested compounds.

\section{Results and Discussion}

Pyrrolo[1,2-a]quinoline and pyrrolo[2,1-a]isoquinoline cores were generated through $[3+2]$ cycloaddition reactions that lead to the formation of in situ (iso)quinolinium ylides [24-27]. Initially, for the introduction of a 4-substituted phenacyl substituent, salts $3 \mathbf{a}-\mathbf{c}$ and $5 \mathbf{a}-\mathbf{c}$ were synthesized by the direct $N$-alkylation of isoquinoline and quinoline, respectively, using para-substituted 2-bromoacetophenones 2a-c (Schemes 1 and 2) [28]. The spectral data of salts $\mathbf{2} \mathbf{a}-\mathbf{b}$ and $\mathbf{3} \mathbf{a}-\mathbf{b}$ are not reported herein, being in agreement with the ones in the existing literature $[29,30]$. 


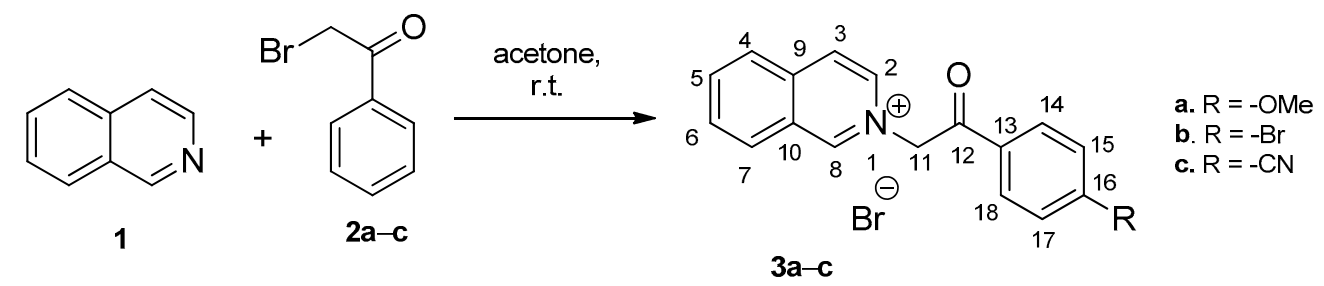

Scheme 1. Synthesis of isoquinolin-2-ium monoquaternary salts 3.

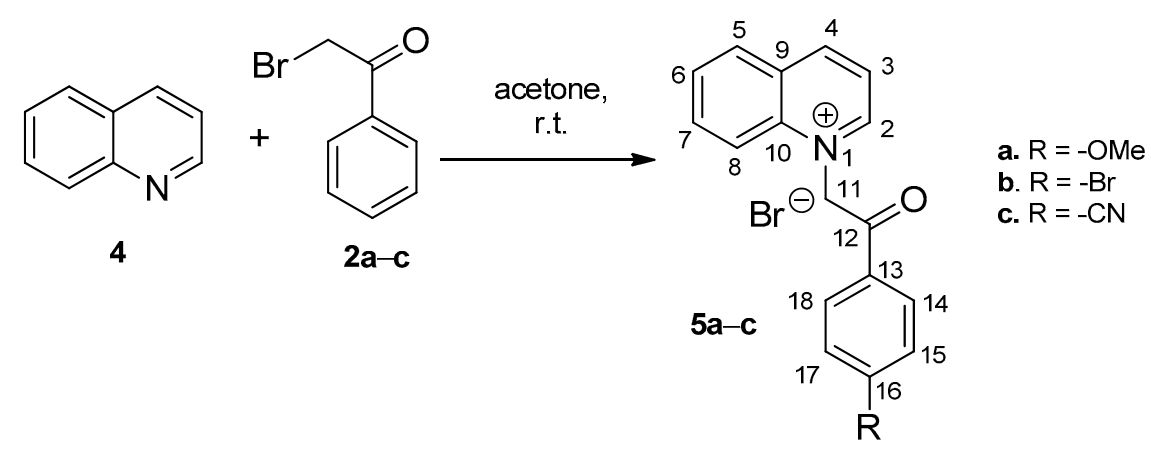

Scheme 2. Synthesis of quinolin-1-ium monoquaternary salts 5.

In the next step, dicyano-substituted fused pyrrole ring derivatives were built through the Huisgen [3+2] cycloaddition of the in situ formed ylides corresponding to the salts 3 and 5 , to fumaronitrile.

Interestingly, following the same experimental protocol consisting in triethylamine treatment of the monoquaternary salt and subsequent cycloaddition to fumaronitrile, we selectively obtained distinct major products in the case of isoquinolin-2-ium salts $\mathbf{3 a - c}$ (Scheme 3).

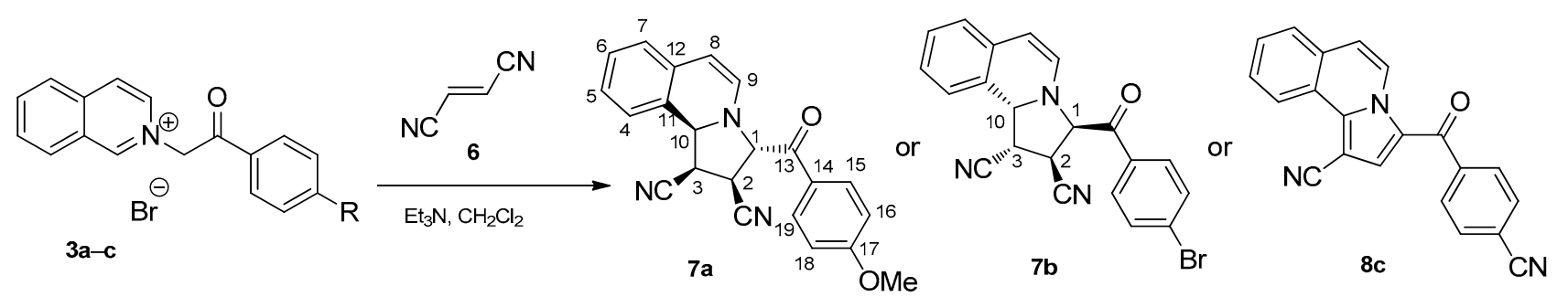

Scheme 3. Synthesis of fused compounds $7 \mathbf{a}-\mathbf{b}$ and $\mathbf{8 c}$.

As expected, derivatives with a 1,2,3,10b-tetrahydropyrrolo[2,1-a]isoquinoline scaffold were generated in the first step (Schemes 4 and 5), but in the case of salt $3 \mathbf{c}$ we discovered that the initial fused cycloadduct $7 \mathrm{c}$ underwent an elimination of the cyano group under triethylamine excess, followed by an oxidative aromatization, leading to the more stable compound 8c (Scheme 5).

The NMR analysis of compounds $7 \mathbf{a}-\mathbf{b}$ confirmed the formation of one major polychiral racemic with a 1,2,3,10b-tetrahydropyrrolo[2,1-a] isoquinoline scaffold, but surprisingly, the geometry of the pyrrole ring is different for compounds $\mathbf{7 a}, \mathbf{b}$ (Scheme 3). 


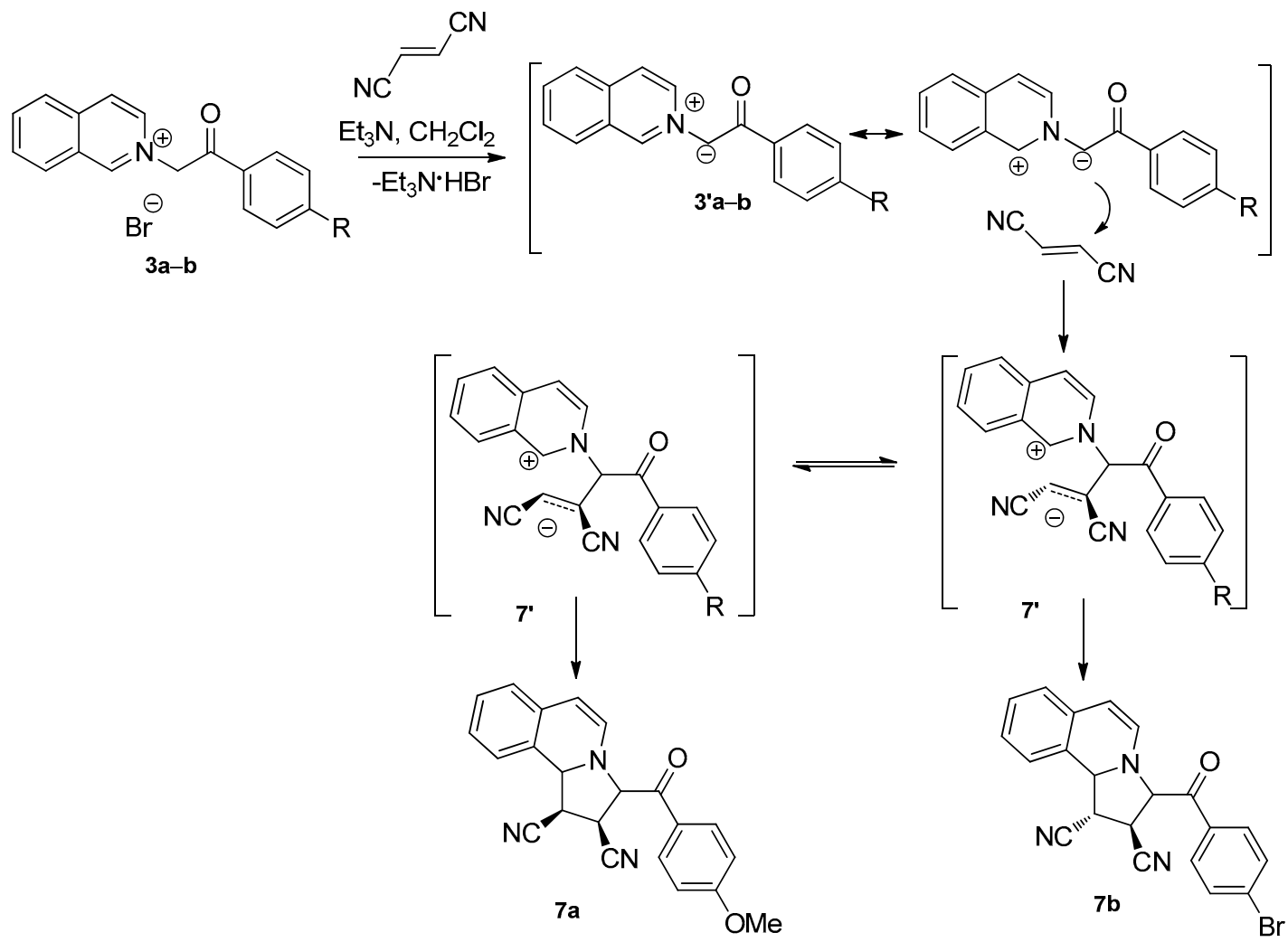

Scheme 4. Synthesis pathway and reaction mechanism for the fused isoquinoline derivatives $7 \mathbf{a}, \mathbf{b}$.
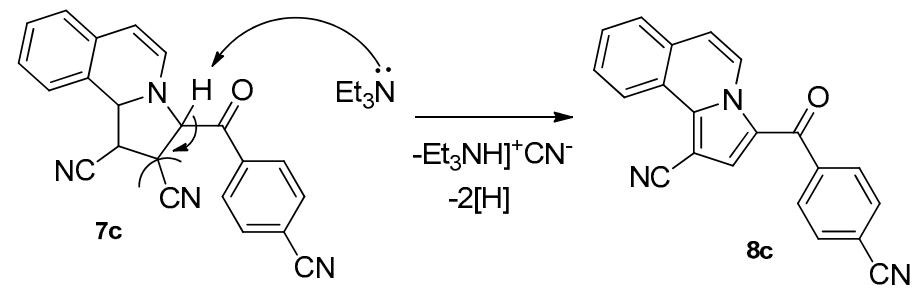

Scheme 5. Proposed reaction mechanism for the formation of fused isoquinoline derivative 8c.

Thus, in the ${ }^{1} \mathrm{H}-\mathrm{NMR}$ spectrum of compound $7 \mathbf{a}$, the signal at $\delta=3.79 \mathrm{ppm}$ was assigned to the $\mathrm{H} 3$ atom, the most shielded proton of the tetrahydropyrrole cycle. Protons 2 and 10 produce signals at $\delta=4.26 \mathrm{ppm}$ and $\delta=4.32 \mathrm{ppm}$, respectively (Table 1 ). The small coupling for the $\mathrm{H} 1$ proton $(\delta=6.04 \mathrm{ppm}, J=2.5 \mathrm{~Hz})$ suggests a trans position relative to proton $\mathrm{H} 2[20,21,29]$. The large values for the coupling constants $J_{2,3}(8.0 \mathrm{~Hz})$ and $J_{3,10}(9.5 \mathrm{~Hz})$ suggests that hydrogen atoms $\mathrm{H} 2, \mathrm{H} 3$ and $\mathrm{H} 10$ lay on the same side of the tetrahydropyrrole ring, but on the opposite side of H1 (Scheme 3, Table 1).

Table 1. Chemical shifts and coupling constants for protons of new formed pyrrole ring in compounds $7 a, b$.

\begin{tabular}{|c|c|c|c|c|c|c|c|}
\hline Compound & $\begin{array}{c}\text { H1 } \\
\delta(\mathrm{ppm})\end{array}$ & $J_{1,2}(\mathrm{~Hz})$ & $\begin{array}{c}\mathrm{H} 2 \\
\delta(\mathrm{ppm})\end{array}$ & $J_{2,3}(\mathrm{~Hz})$ & $\begin{array}{c}\text { H3 } \\
\delta(\mathrm{ppm})\end{array}$ & $J_{3,10}(\mathrm{~Hz})$ & $\begin{array}{c}\text { H10 } \\
\delta(\mathrm{ppm})\end{array}$ \\
\hline $7 a$ & 6.04 & 2.50 & 4.26 & 8.00 & 3.79 & 9.50 & 4.32 \\
\hline $7 b$ & 6.00 & 8.00 & 4.33 & 4.50 & 4.40 & 6.50 & 5.04 \\
\hline
\end{tabular}

In the ${ }^{1} \mathrm{H}-\mathrm{NMR}$ spectrum of compound $\mathbf{7 b}$, the signal produced by $\mathrm{H} 1$ appears as a doublet at weak fields $(\delta=6.00 \mathrm{ppm})$ due to its electron-withdrawing neighbors. The strong coupling for the $\mathrm{H} 1$ proton $(J=8.00 \mathrm{~Hz})$ suggests a cis position relative to proton 2 
(Table 1). Also deshielded is proton H10 that furnished a doublet at $\delta=5.04 \mathrm{ppm}$ with a large coupling constant $(J=6.50 \mathrm{~Hz})$, suggesting a cis position relative to proton 3 . Protons 2 and 3 supply signals at $\delta=4.33 \mathrm{ppm}$ and $\delta=4.40 \mathrm{ppm}$, respectively. The low value for the coupling constant $J_{2,3}(4.5 \mathrm{~Hz})$ is evidence that hydrogen atoms $\mathrm{H} 2$ and $\mathrm{H} 3$ are positioned on opposing sides of the tetrahydropyrrole ring. Taken together, these data show that in the case of compound $\mathbf{7 b}$, hydrogen atoms $\mathrm{H} 1$ and $\mathrm{H} 2$ are positioned on the same side of the tetrahydropyrrole ring, but on the opposite side of $\mathrm{H} 3$ and $\mathrm{H} 10$.

In particular, the generated products have a relative configuration of the nitrile groups identical to that observed in the alkene (compound $\mathbf{7 b}$ ), as well as reversed (compound 7a). The loss of the stereo-configuration contributed from the starting material in compound $7 \mathbf{a}$ indicates that a rotation around the NC-C-C-CN bond must have occurred in the course of the reaction. This implies a process that involves the asynchronous formation of new $\sigma$ bonds and the necessity of the appearance of isomerization of the acyclic zwitterion intermediates type $7^{\prime}$ (Scheme 4) [31,32]. Even if Huisgen [3 + 2] cycloadditions are commonly recognized as taking place in a one-step mechanism, our observations consolidate existing instances of such reactions that can occur in accordance with multi-step mechanisms with the participation of zwitterion intermediates [31-33].

Similarly, by deprotonation of quinolin-1-ium salts $5 \mathbf{a}-\mathbf{c}$ under triethylamine treatment, the in situ generated resonance stabilized $N$-ylides reacted with fumaronitrile to give tetrahydropyrrolo[1,2-a] quinolines $\mathbf{9 a - b}$ and pyrrolo[1,2-a]quinoline $\mathbf{1 0} \mathbf{c}$, respectively (Scheme 6).<smiles></smiles>

5a-c

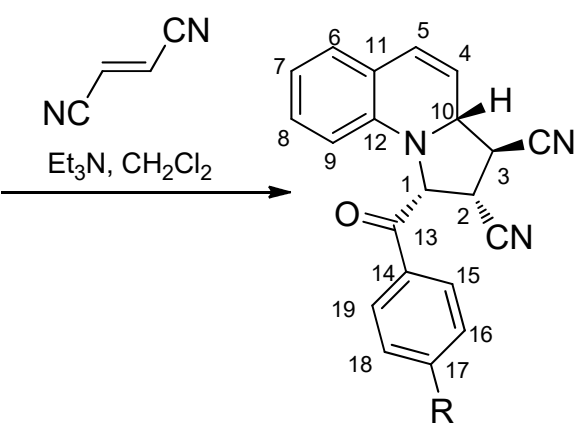

9a-b<smiles>N#Cc1ccc(C(=O)c2c(C#N)c(C(N)=O)c3ccc4ccccc4n23)cc1</smiles>

$10 \mathrm{c}$

Scheme 6. Synthesis of fused quinoline compounds $9 a, b$ and $10 c$.

The cycloaddition reactions to fumaronitrile occured stereoselectively, a single major polychiral isomer being obtained in case of salts $\mathbf{5 a - b}$. In these cycloaddition reactions, the trans stereo-configuration of fumaronitrile was preserved in the pyrrole ring of compounds 9a-b (Scheme 6). The coupling constants of protons H1, H2, H3 and H10 (Scheme 6, Table 2) indicate that protons $\mathrm{H} 1, \mathrm{H} 2$ and $\mathrm{H} 10$ lay on the same side of the tetrahydropyrrole ring, but on the opposite side of $\mathrm{H} 3$.

Table 2. Chemical shifts and coupling constants for protons of new formed pyrrole ring in compounds 9a,b.

\begin{tabular}{cccccccc}
\hline Compound & $\begin{array}{c}\mathbf{H 1} \\
\boldsymbol{\delta}(\mathbf{p p m})\end{array}$ & $\boldsymbol{J}_{\mathbf{1 , 2}} \mathbf{( H z )}$ & $\begin{array}{c}\mathbf{H 2} \\
\boldsymbol{\delta}(\mathbf{p p m})\end{array}$ & $\boldsymbol{J}_{\mathbf{2 , 3}} \mathbf{( H z )}$ & $\begin{array}{c}\mathbf{H 3} \\
\boldsymbol{\delta}(\mathbf{p p m})\end{array}$ & $\boldsymbol{J}_{\mathbf{3}, \mathbf{1 0}} \mathbf{( H z )}$ & $\begin{array}{c}\mathbf{H 1 0} \\
\boldsymbol{\delta}(\mathbf{p p m})\end{array}$ \\
\hline $\mathbf{9 a}$ & 5.89 & 9.00 & 4.72 & 4.00 & 4.21 & - & 5.12 \\
\hline $\mathbf{9 b}$ & 5.96 & 9.00 & 4.72 & 4.00 & 4.22 & 2.00 & 5.10 \\
\hline
\end{tabular}

The stereoselectivity of the cycloaddition of salt $5 \mathrm{c}$ to fumaronitrile cannot be discussed, as in this case the main product obtained was aromatized 2-cyano-1-(4-cyanobenzoyl) pyrrolo[1,2-a]quinoline-3-carboxamide 10c, due to the hydrolysis of one of the cyano groups at the pyrrole ring. 
Eleven compounds were selected for assessment of anticancer activity, which was performed according to the standard protocols of National Cancer Institute (NCI, Rockville, MD, USA). Thus, compounds $\mathbf{3 a}-\mathbf{c}, \mathbf{5} \mathbf{a}-\mathbf{c}, \mathbf{7 a}-\mathbf{b}, \mathbf{8} \mathbf{c}$ and $\mathbf{9 a}, \mathbf{b}$ and control phenstatin were first tested at a single high dose $\left(10^{-5} \mathrm{M}\right)$ against a panel of 60 cell lines representing different types of cancers including leukemia, melanoma, lung, colon, CNS, ovarian, renal, prostate and breast cancers [34-36]. The results obtained at this stage are summarized in Table 3.

Table 3. Results of the in vitro growth inhibition $\left(\mathrm{GI} \%, 10^{-5} \mathrm{M}\right)$ caused by compounds $\mathbf{3 a} \mathbf{a}, \mathbf{b}, \mathbf{5} \mathbf{a}-\mathbf{c}, \mathbf{7} \mathbf{a}, \mathbf{b}, \mathbf{8} \mathbf{c}$ and $\mathbf{9 a}, \mathbf{b}$ against human cancer cell lines in the single-dose assay ${ }^{a}$.

\begin{tabular}{|c|c|c|c|c|c|c|c|c|c|c|c|c|c|}
\hline \multirow{2}{*}{ Cell Type } & \multirow{2}{*}{ Cell Line } & \multicolumn{12}{|c|}{ Compound } \\
\hline & & $3 a$ & $3 b$ & $3 c$ & $5 a$ & $5 b$ & $5 c$ & $7 a$ & $7 \mathrm{~b}$ & $8 c$ & $9 a$ & $9 b$ & Phenstatin \\
\hline \multirow{6}{*}{ Leukemia } & CCRF-CEM & 8 & 6 & 2 & 1 & 0 & 0 & 18 & 0 & 0 & 84 & 15 & 94 \\
\hline & K-562 & 4 & 20 & 0 & 11 & 17 & 7 & 27 & 0 & 12 & 88 & 76 & 91 \\
\hline & SR & 0 & 6 & 0 & 0 & 0 & 3 & 0 & 0 & 25 & 79 & 75 & 93 \\
\hline & HL-60(TB) & 0 & 14 & 0 & 2 & 0 & 1 & 6 & 0 & 8 & $100^{b, d}$ & 6 & $100^{b, 1}$ \\
\hline & MOLT-4 & 3 & 7 & 2 & 0 & 0 & 0 & 5 & 0 & 7 & 63 & 8 & 85 \\
\hline & RPMI-8226 & 0 & 6 & 3 & 0 & 1 & 0 & 27 & 0 & 0 & 70 & 6 & 87 \\
\hline \multirow{5}{*}{$\begin{array}{l}\text { Non-small Cell } \\
\text { Lung Cancer }\end{array}$} & A549/ATCC & 0 & 3 & 1 & 2 & 2 & 0 & 13 & 17 & 10 & 70 & 35 & 82 \\
\hline & HOP-92 & 18 & 31 & 24 & 15 & 24 & 14 & 15 & 5 & 20 & 16 & 45 & 48 \\
\hline & HOP-62 & 10 & 18 & 9 & 3 & 13 & 0 & 7 & 3 & 66 & 70 & 25 & 77 \\
\hline & NCI-H460 & 0 & 3 & 0 & 0 & 0 & 0 & 3 & 13 & 28 & 81 & 4 & 93 \\
\hline & NCI-H522 & 8 & 11 & 2 & 8 & 6 & 4 & 29 & 12 & 36 & 100 & 22 & 88 \\
\hline \multirow{6}{*}{ Colon Cancer } & COLO205 & 1 & 18 & 8 & 0 & 0 & 0 & 0 & 0 & 0 & $100^{\mathrm{b}, \mathrm{e}}$ & 97 & 58 \\
\hline & НCТ-116 & 3 & 27 & 11 & 4 & 5 & 2 & 14 & 13 & 15 & 85 & 32 & 96 \\
\hline & НСТ-15 & 2 & 5 & 2 & 8 & 1 & 0 & 5 & 4 & 5 & 83 & 77 & 96 \\
\hline & НТ-29 & 5 & 33 & 0 & 3 & 2 & 5 & 16 & 14 & 20 & 93 & 63 & 85 \\
\hline & SW-620 & 7 & 13 & 9 & 5 & 8 & 4 & 82 & 0 & 8 & 74 & 34 & 78 \\
\hline & KM12 & 6 & 10 & 1 & 1 & 2 & 4 & 2 & 0 & 10 & 94 & 78 & 91 \\
\hline \multirow{4}{*}{ CNS Cancer } & SF-295 & 3 & 17 & 2 & 7 & 5 & 5 & 5 & 4 & 36 & 78 & 11 & $100^{b, m}$ \\
\hline & SF-539 & 1 & 8 & 5 & 0 & 0 & 2 & 5 & 11 & 52 & $100^{\mathrm{b}, \mathrm{f}}$ & 11 & $100^{\mathrm{b}, \mathrm{n}}$ \\
\hline & SNB-75 & 20 & 24 & 30 & 29 & 29 & 17 & 26 & 10 & 67 & $100^{b, f}$ & 88 & $100^{b, o}$ \\
\hline & U251 & 0 & 1 & 2 & 3 & 0 & 0 & 7 & 0 & 15 & 66 & 16 & 79 \\
\hline \multirow{6}{*}{ Melanoma } & LOX IMVI & 5 & 14 & 2 & 6 & 7 & 8 & 13 & 8 & 20 & 57 & 22 & 85 \\
\hline & M14 & 5 & 13 & 8 & 7 & 6 & 5 & 6 & 0 & 3 & $100^{b, g}$ & 25 & $100^{b, p}$ \\
\hline & MDA-MB-435 & 0 & 8 & 2 & 0 & 2 & 0 & 4 & 0 & 0 & $100^{b, h}$ & 84 & $100^{\mathrm{b}, \mathrm{r}}$ \\
\hline & UACC-62 & 14 & 18 & 0 & 11 & 11 & 13 & 37 & 2 & 35 & 53 & 37 & 55 \\
\hline & SK-MEL-2 & 0 & 3 & 0 & 0 & 0 & 0 & 12 & 2 & 7 & 66 & 0 & 40 \\
\hline & SK-MEL-5 & 0 & 2 & 0 & 0 & 1 & 0 & 14 & 10 & 11 & 85 & 39 & $100^{b, s}$ \\
\hline \multirow{5}{*}{ Ovarian Cancer } & OVCAR-3 & 3 & 21 & 0 & 0 & 3 & 0 & 8 & 0 & 8 & $100^{b, i}$ & 25 & $100^{b, g}$ \\
\hline & NCI/ADR-RES & 3 & 6 & 2 & 2 & 0 & 0 & 13 & 6 & 45 & $100^{b, d}$ & 36 & $100^{b, t}$ \\
\hline & SK-OV-3 & 3 & 19 & 4 & 0 & 18 & 1 & 7 & 0 & 0 & 45 & 21 & 53 \\
\hline & OVCAR-4 & 3 & 17 & 4 & 0 & 9 & 0 & 38 & 46 & 57 & 54 & 57 & 69 \\
\hline & OVCAR-8 & 3 & 2 & 5 & 2 & 3 & 0 & $100^{b, c}$ & 6 & 58 & 73 & 10 & 86 \\
\hline \multirow{3}{*}{ Renal cancer } & A498 & 7 & 11 & 56 & 0 & 5 & 3 & 20 & 0 & 5 & $100^{b, j}$ & 33 & 25 \\
\hline & RXF393 & 1 & 7 & 0 & 0 & 1 & 0 & 23 & 0 & 25 & $100^{\mathrm{b}, \mathrm{k}}$ & 25 & 99 \\
\hline & UO-31 & 19 & 29 & 17 & 14 & 20 & 18 & 40 & 1 & 16 & 68 & 52 & 67 \\
\hline \multirow{4}{*}{ Breast cancer } & MCF7 & 8 & 14 & 11 & 11 & 17 & 10 & 9 & 8 & 17 & 92 & 87 & 94 \\
\hline & MDA-MB-468 & 10 & 16 & 10 & 4 & 9 & 15 & 36 & 0 & 23 & 84 & $100^{b, d}$ & $100^{b, u}$ \\
\hline & HS 578T & 5 & 9 & 6 & 10 & 8 & 5 & 5 & 0 & 50 & 86 & 23 & 71 \\
\hline & BT-549 & 0 & 0 & 5 & 0 & 0 & 0 & 5 & 0 & 47 & 47 & 7 & 88 \\
\hline \multirow{2}{*}{ Prostate cancer } & PC-3 & 11 & 18 & 8 & 10 & 13 & 9 & 16 & 6 & 39 & 71 & 24 & 80 \\
\hline & DU-145 & 0 & 0 & 0 & 0 & 0 & 0 & 0 & 3 & 18 & 76 & 9 & 90 \\
\hline
\end{tabular}

${ }^{\mathrm{a}}$ Data obtained from NCI's in vitro 60 cell one dose screening at $10^{-5} \mathrm{M}$ concentration; ${ }^{\mathrm{b}}$ Cytotoxic effect; Cell growth percent: ${ }^{\mathrm{c}}-5 ;{ }^{\mathrm{d}}-8$;

e $-6 ;^{\mathrm{f}}-21 ; \mathrm{g}-7 ;^{\mathrm{h}}-48 ;^{\mathrm{i}}-12 ;^{\mathrm{j}}-10 ;^{\mathrm{k}} 22{ }^{\mathrm{l}}-29 ;^{\mathrm{m}}-9 ;^{\mathrm{n}}-22 ;^{\mathrm{o}}-1 ;^{\mathrm{p}}-4 ;^{\mathrm{r}}-41 ;^{\mathrm{s}}-60 ;^{\mathrm{t}}-32{ }^{\mathrm{u}}-14$.

Overall, compounds $\mathbf{9 a , b}$, which possess a 1,2,3,3a-tetrahydropyrrolo[1,2-a]quinoline2,3-dicarbonitrile structure, exhibited good activity against a large number of cancer cells from each panel. In particular, compound 9a showed a broad spectrum of cytotoxic activity against several of the tested cancer cell lines, the best activity being registered 
against melanoma MDA-MB-435 cells. Compound $9 \mathbf{b}$ also proved to be cytotoxic against breast cancer MDA-MB-468 cells. The other tested compounds were inactive, except for compound $7 \mathbf{a}$ that selectively inhibited the growth of ovarian cancer OVCAR-8 cells and colon cancer SW-620 cells, as well as compound 8c, which showed moderate inhibition of several cancer cell lines.

Only compounds which satisfied pre-determined threshold inhibition criteria in a minimum number of cell lines progressed to the full 5-dose assay. The threshold inhibition criteria for progression to the 5-dose screen are used to efficiently capture compounds with anti-proliferative activity based on the careful analysis of in-house screening data available at the Developmental Therapeutics Program at NCI (https: / / dtp.cancer.gov / discovery_ development/nci-60/methodology.htm) (accessed on 2 March 2021).

Due to a broad range of cytostatic and cytotoxic effects, compound $9 \mathbf{a}$ was selected for detailed studies at five different concentrations $(0.01,0.1,1,10$ and $100 \mu \mathrm{M})$ in the 5-dose assay [34-36]. The results are represented in terms of response parameter $\mathrm{GI}_{50}$, defined as the required molar concentration to inhibit $50 \%$ of the growth of cancer cells. Relevant $\mathrm{GI}_{50}$ values calculated for compound 9a against cells of all nine cancer types are summarized in Table 4.

Table 4. Results of the 5-dose in vitro human cancer cell growth inhibition a for compound 9a.

\begin{tabular}{|c|c|c|}
\hline \multirow{2}{*}{ Cell Type } & Compound & $9 a$ \\
\hline & Cell Line & $\mathrm{GI}_{50}(\mu \mathrm{M})^{b}$ \\
\hline \multirow{3}{*}{ Leukemia } & HL-60(TB) & 1.23 \\
\hline & $\mathrm{SR}$ & 0.544 \\
\hline & K-562 & 0.405 \\
\hline \multirow{3}{*}{ Non-small Cell Lung Cancer } & NCI-H460 & 0.749 \\
\hline & NCI-H522 & 2.45 \\
\hline & A549/ATCC & 2.40 \\
\hline \multirow{5}{*}{ Colon Cancer } & HCT-116 & 0.653 \\
\hline & НCТ-15 & 0.197 \\
\hline & HT29 & 0.844 \\
\hline & SW-620 & 0.715 \\
\hline & KM12 & 1.25 \\
\hline \multirow{2}{*}{ Prostate cancer } & PC-3 & 1.45 \\
\hline & DU-145 & 2.93 \\
\hline \multirow{7}{*}{ Melanoma } & SK-MEL-5 & 3.49 \\
\hline & M14 & 0.50 \\
\hline & MDA-MB-435 & 0.335 \\
\hline & UACC-62 & 0.781 \\
\hline & LOXIMVI & 2.10 \\
\hline & MALME-3M & 2.67 \\
\hline & Cell line & $\mathrm{GI}_{50}(\mu \mathrm{M})^{\mathrm{b}}$ \\
\hline \multirow{4}{*}{ Ovarian Cancer } & OVCAR-3 & 0.642 \\
\hline & NCI/ADR-RES & 0.572 \\
\hline & IGROV1 & 2.74 \\
\hline & OVCAR-8 & 3.29 \\
\hline \multirow{5}{*}{ Renal Cancer } & CAKI-1 & 0.460 \\
\hline & A498 & 0.244 \\
\hline & UO-31 & 1.95 \\
\hline & $\mathrm{ACHN}$ & 1.43 \\
\hline & RXF 393 & 1.52 \\
\hline
\end{tabular}


Table 4. Cont.

\begin{tabular}{ccc}
\hline \multirow{2}{*}{ Cell Type } & Compound & $\mathbf{9 a}$ \\
\cline { 2 - 3 } & Cell Line & GI $_{\mathbf{5 0}}(\boldsymbol{\mu \mathbf { M }})^{\mathbf{b}}$ \\
\hline & MCF7 & 1.09 \\
& HS 578T & 2.10 \\
Breast cancer & MDA-MB-231/ATCC & 1.46 \\
& BT-549 & 1.98 \\
& T-47D & 2.39 \\
& MDA-MB-468 & 2.31 \\
\hline CNS Cancer & SF-295 & 2.83 \\
& SF-539 & 1.32 \\
& SNB-75 & 0.278 \\
& U251 & 2.81 \\
\hline
\end{tabular}

a Data obtained from from NCI's in vitro 60 cell 5-dose screening. ${ }^{b} \mathrm{GI}_{50}$-the molar concentration of tested compound causing $50 \%$ growth inhibition of tumor cells.

The in vitro screening results revealed that compound 9a possesses excellent antiproliferative activity, with $\mathrm{GI}_{50}$ values ranging from 0.197 to $3.49 \mu \mathrm{M}$ against 40 cancer cells from all nine sub-panels. Compound 9 a showed the best $\mathrm{GI}_{50}$ and total growth inhibition (TGI) values (197 nM and $278 \mathrm{nM}$, respectively) against HCT-15 colon cancer and SNB-75 CNS cancer.

In order to estimate the toxicity of the most active compound $9 \mathbf{a}$, we used the webservice Cell-Line Cytotoxicity Predictor (CLC-Pred), which screens for cytotoxicity in silico on a panel of 278 tumour cells and 27 normal human cell lines from different tissues [37]. The predicted toxicity spectrum is represented by a list of activities with probabilities "to be active" $P a$ and "to be inactive" $P i$. The results (Table 5) predicted cytotoxicity $\left(\mathrm{P}_{\mathrm{a}}>\mathrm{P}_{\mathrm{i}}\right.$ and $\mathrm{P}_{\mathrm{a}}>0.3$ ) against several cancer cell lines, including two of the tested NCI cell lines: DU-145 and PC-3 (Tables 3 and 4). The fact that no normal human cell lines appeared on the list could be an indication for a good selectivity of compound 9a against cancer cell lines. However, in vitro testing should be performed in order to confirm these theoretical results.

Table 5. Results of for the prediction of cytotoxicity of compound 9a.

\begin{tabular}{llll}
\hline $\mathbf{P}_{\mathbf{a}}$ & $\mathbf{P}_{\mathbf{i}}$ & Cell Line & Cell Type \\
\hline 0.698 & 0.009 & DU-145 & Prostate carcinoma \\
\hline 0.521 & 0.004 & A-375 & Malignant melanoma \\
\hline 0.500 & 0.029 & PC-3 & Prostate carcinoma \\
\hline 0.438 & 0.035 & A2058 & Melanoma \\
\hline 0.308 & 0.007 & LNCaP & Prostate carcinoma \\
\hline 0.399 & 0.100 & YAPC & Pancreatic carcinoma \\
\hline 0.391 & 0.125 & Hs 683 & Oligodendroglioma \\
\hline 0.340 & 0.080 & U-266 & Plasma cell myeloma \\
\hline 0.323 & 0.214 & NALM-6 & Adult B acute lymphoblastic leukemia \\
\hline 0.329 & 0.249 & MDA-MB-453 & Breast adenocarcinoma \\
\hline
\end{tabular}

Cai and collab. previously reported in literature several compounds with pyrrolo[1,2a]quinoline structure and anticancer activity that induced apoptosis by inhibiting tubulin polymerization $[14,15]$. Therefore, in order to confirm if the observed anticancer activity is related to a microtubule-targeting mechanism, we evaluated the effect of the active compound 9a on tubulin polymerization (Figure 2). Paclitaxel (as tubulin stabiliser) and phenstatin (as tubulin polymerisation inhibitor) were used as positive controls. 


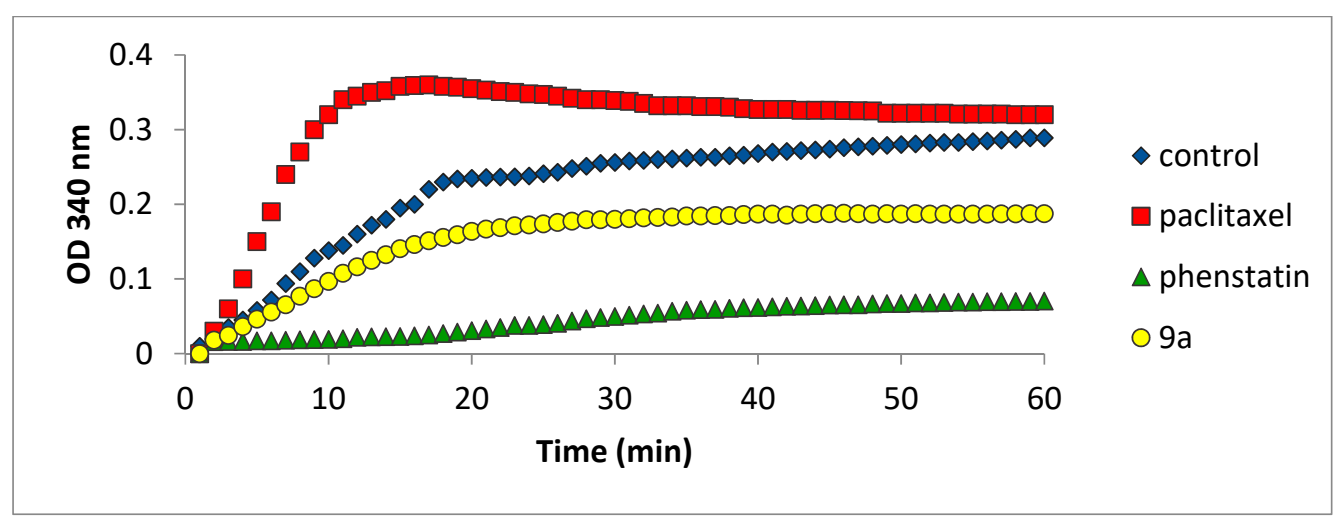

Figure 2. Effect of compound $9 \mathrm{a}\left(10^{-5} \mathrm{M}\right)$ on microtubule dynamics using paclitaxel $\left(10^{-5} \mathrm{M}\right)$ as microtubule stabilising control agent and phenstatin $\left(10^{-5} \mathrm{M}\right)$ as microtubule destabilising control agent.

As can be seen in Figure 2, paclitaxel was found to stimulate tubulin polymerisation, while phenstatin and compound 9a inhibited tubulin polymerisation. However, the tubulin polymerization inhibition potency of compound 9a was much lower than the one showed by phenstatin, this fact suggesting that other possible mechanisms could be considered for the observed anticancer activity of compound $9 a$.

In order to gain more insights regarding a possible interaction of the anticancer tested compounds with tubulin, we carried out the molecular docking of compounds $\mathbf{3 a}-\mathbf{c}, \mathbf{5 a}-\mathbf{c}$, $7 \mathbf{a}, \mathbf{b}, \mathbf{8 c}$ and $\mathbf{9 a}, \mathbf{b}$ in the colchicine binding site of tubulin.

Simple isoquinoline and quinoline analogues were accommodated in the colchicine binding site in two distinct orientation modes, dependent on base ring structure. Isoquinolines $3 \mathbf{a}-\mathbf{c}$ roughly occupied the same space as phenstatin in the tubulin binding site regardless of second ring substituents, although in a flipped manner when compared to other heterocyclic compounds with pronounced anticancer activity [19]. Thus, the isoquinoline moiety overlapped with the trimethoxysubstituted ring of phenstatin, being stabilized exclusively through hydrophobic interactions with side chains mainly in the $\beta$ subunit ( $\beta$ Cys241, $\beta$ Leu255, $\beta$ Leu242, $\beta$ Ala250, $\beta$ Leu248, $\alpha$ Ala180). This has been previously seen with other heterocyclic compounds possessing low anticancer activity, yet ability to inhibit tubulin polymerization in vitro [17]. Quinolines 5a-c spanned the dimer interface by anchoring to $\beta$ Asn 258 and engaging in hydrophobic contacts with fewer $\beta$ subunit side chains when compared to more active compounds (Table 6). The quinoline moiety was not buried deep in the binding site, as seen for isoquinoline analogues, and lacked any interaction with $\beta$ Cys241, which is known to be important for the activity of other antitumor compounds which bind to the colchicine binding site [38,39]. However, the H-bond between the central carbonyl and $\beta$ Asn 258 permitted a favorable geometry for $\pi-\sigma$ stacking between the quinoline ring and $\beta$ Leu248, which has also been seen for some anticancer triazole derivatives [40]. The second ring was oriented toward the $\alpha$ subunit, and in the case of compound $\mathbf{5 c}$, the best scoring quinoline derivative, engaged in polar contacts with $\alpha \mathrm{Ty} 224$ and $\alpha \mathrm{Gln} 11$ through its cyano substituent. Compound $3 \mathrm{c}$ also had a conformation which formed hydrogen bonds with $\alpha$ Tyr224 and $\alpha \mathrm{Gln} 11$ through its cyano substituent, but of lower binding energy (not shown), indicating that such a binding orientation could also be possible for isoquinoline derivatives, provided the substituents are adequate for hydrogen bond formation. 
Table 6. Binding orientation, energy and amino acid contacts for tested compounds, as predicted by molecular docking experiments. For binding orientation, the $\alpha, \beta$-tubulin heterodimer is shown as ribbons (red/yellow/green- $\alpha$ subunit helices/sheets/loops; pink/orange/magenta- $\beta$ subunit helices/sheets/loops); relevant aminoacids, GTP and ligands are represented as sticks; for 2D interaction diagrams, colors are as follows: conventional hydrogen bonds-green, carbonhydrogen bonds-pale green; hydrophobic interactions-light pink; amide-pi stacking-dark pink; pi-sigma stacking-purple.

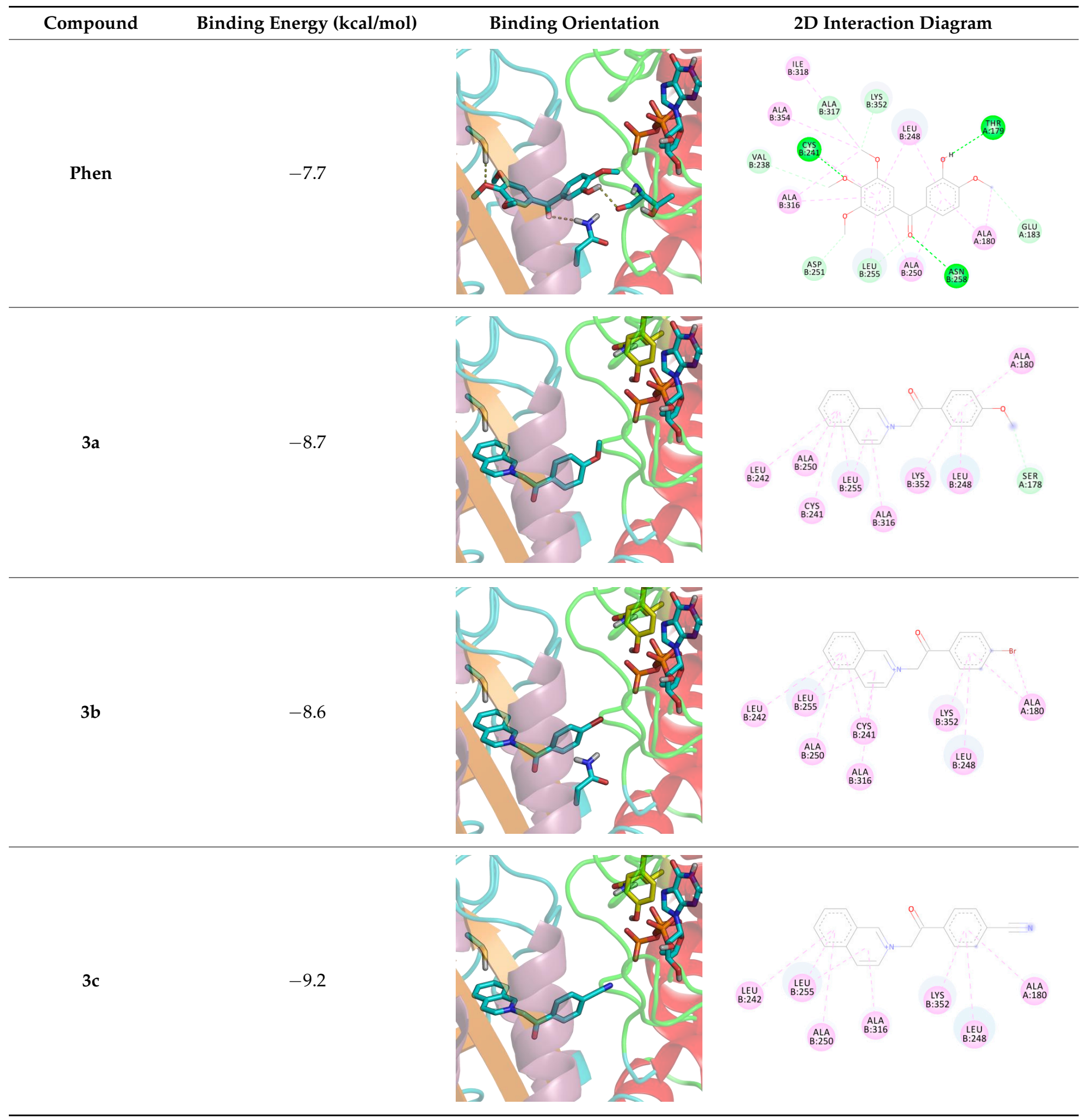


Table 6. Cont.

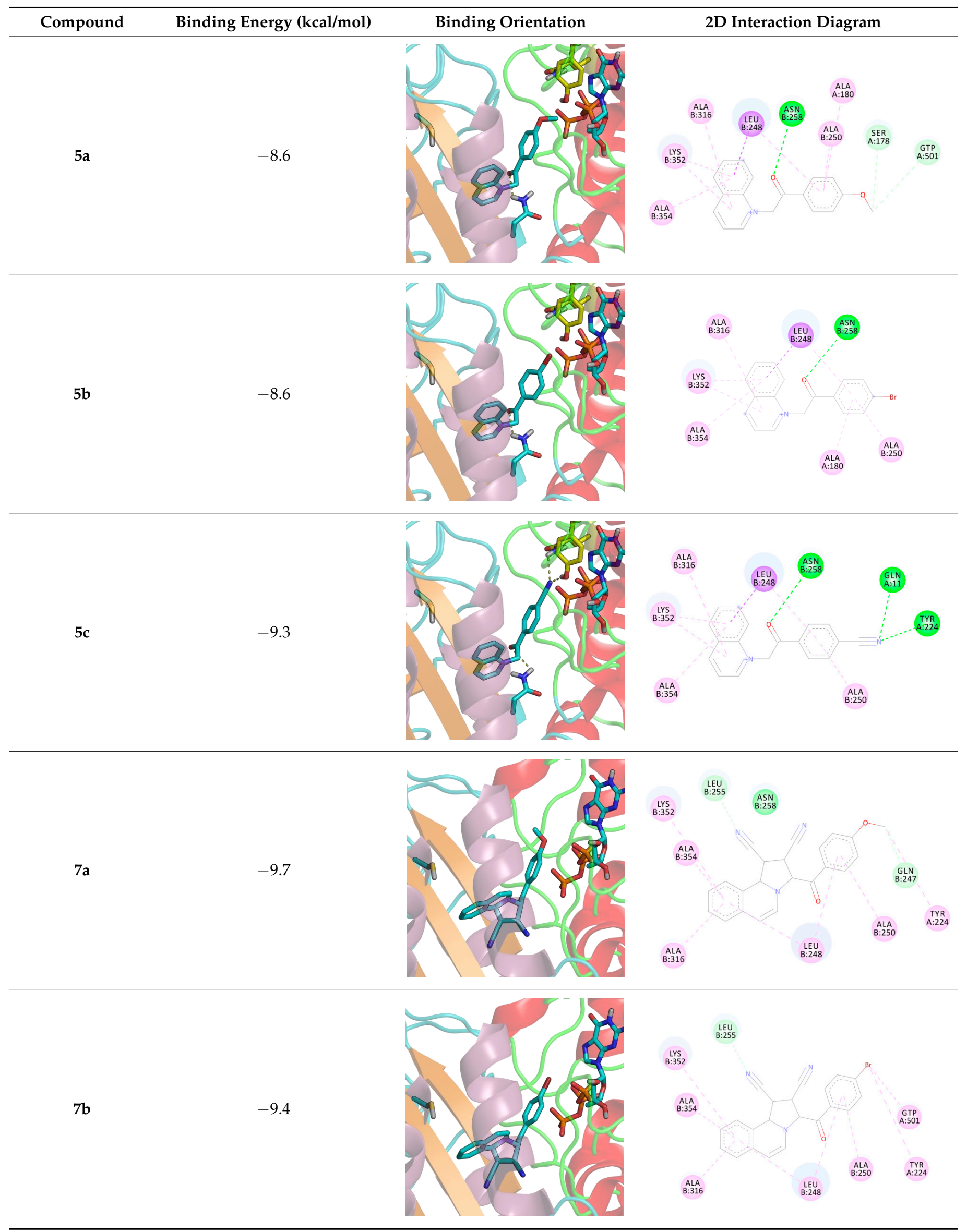


Table 6. Cont

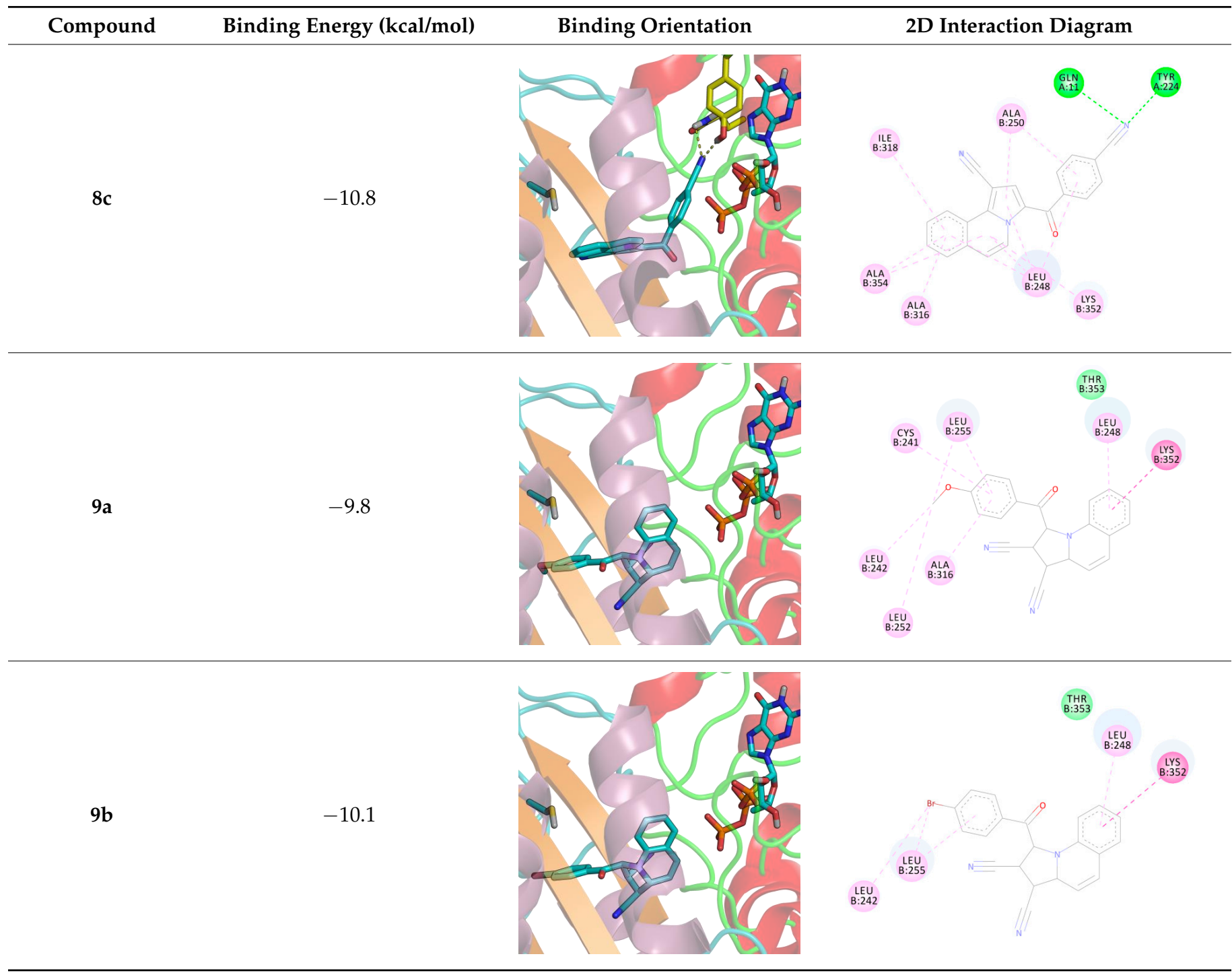

The slightly more active cycloadducts $\mathbf{7 a}, \mathbf{b}$ and $\mathbf{8 c}$ were accommodated in the binding pocket similar to quinolines $\mathbf{5} \mathbf{a}-\mathbf{c}$ rather than parent isoquinolines $\mathbf{3} \mathbf{a}-\mathbf{c}$, and were stabilized mostly by hydrophobic contacts with aminoacids in the $\beta$ subunit, with the exception of 8c, which established additional contacts with $\alpha$ Tyr224 and $\alpha$ Gln 11 through its cyano substituent, similar to $5 \mathbf{c}$, having one of the lowest binding energies of all docked compounds (Table 6).

Interestingly, compounds $\mathbf{9 a}, \mathbf{b}$ had overlapping poses and very good binding energies for two distinct conformations, the first of which are similar to other previously described active phenstatin analogues [18] (lowest binding energy $-9.8 \mathrm{kcal} / \mathrm{mol}$ and $-10.2 \mathrm{kcal} / \mathrm{mol}$, respectively), stabilized mainly by hydrophobic contacts with $\beta$ Leu242, $\beta$ Leu248, $\beta$ Leu255 and an amide-pi stacking interaction between the quinoline moiety and the backbone $\mathrm{NH}$ of $\beta$ Lys352. The other conformations were slightly less energetically favorable $(-9.4 \mathrm{kcal} / \mathrm{mol}$ and $-9.1 \mathrm{kcal} / \mathrm{mol}$, respectively, not shown), were flipped and extended toward the GTP molecule with the substituted benzoyl moiety, being stabilized through extensive hydrophobic contacts with $\beta$ Cys241, $\beta$ Leu248, $\beta$ Ala250, $\beta$ Leu255 and a hydrogen bond interaction between the carbonyl oxygen and the sidechain of $\beta$ Asn258, similar to what was observed for the simpler inactive quinoline analogues $5 \mathbf{a}-\mathbf{c}$ and compounds $\mathbf{7 a} \mathbf{a} \mathbf{b}$ and $\mathbf{8 c}$. Thus, it is possible that the stability of two such distinct conformations in the binding site confers the pyrrolo[1,2-a]quinoline derivatives a more pronounced anticancer activity when 
compared to their pyrrolo[2,1-a]isoquinoline analogues, and at the same time could explain the more pronounced anticancer activity of pyrrolo[2,1-a]quinolines when compared to simple quinoline analogues. However, the stability of these docked conformations should be investigated through subsequent molecular dynamics experiments. For docking protocol validation, we obtained a RMSD value of $0.086 \AA$ A between the co-crystallized conformation and best scoring pose of re-docked colchicine. Generally, a RMSD value below $2 \AA$ (the average resolution of a crystal structure) is considered acceptable [41].

\section{Materials and Methods}

\subsection{Chemistry}

All commercially available reagents and solvents employed were used without further purification. Melting points were recorded on an Optronic Melting Point Meter KSP1 (A. Krüss, Hamburg, Germany) and are uncorrected. Analytical thin-layer chromatography was performed with commercial silica gel plates 60 F254 (Merck, Darmstadt, Germany) and visualized with UV light $\left(\lambda_{\max }=254\right.$ or $\left.365 \mathrm{~nm}\right)$. The NMR spectra were recorded on an Avance III $500 \mathrm{MHz}$ spectrometer (Bruker, Vienna, Austria) operating at $500 \mathrm{MHz}$ for ${ }^{1} \mathrm{H}$ and $125 \mathrm{MHz}$ for ${ }^{13} \mathrm{C}$. Chemical shifts $(\delta)$ were reported in part per million (ppm) and coupling constants $(J)$ in Hz. The following abbreviations were used to designate chemical shift multiplicities: $\mathrm{s}=$ singlet, $\mathrm{d}=$ doublet, $\mathrm{t}=$ triplet, $\mathrm{q}=$ quartet, $\mathrm{m}=$ multiplet, $\mathrm{bs}=$ broad singlet. Infrared (IR) data were recorded as films on potassium bromide (KBr) pellets on a Prestige 8400s FT-IR spectrophotometer (Shimadzu, Kyoto, Japan) or a 660 plus FTIR spectrophotometer (Jasco, Tokyo, Japan). Analyses indicated by the symbols of the elements or functions were within $\pm 0.4 \%$ of the theoretical values.

\subsubsection{General Procedure for Synthesis of Isoquinolinium and Quinolinium Salts $\mathbf{3}$ and $\mathbf{5}$}

One mmol of isoquinoline 1 or quinoline 4 was dissolved in $5 \mathrm{~mL}$ acetone. Then, $1.1 \mathrm{mmol}$ of reactive halide $\mathbf{2 a}-\mathbf{c}$ was added and the resultant mixture was stirred at room temperature (rt) for $24 \mathrm{~h}$. The precipitate formed was filtered off and washed with acetone to give the desired product.

3.1.2. General Procedure for Synthesis of Isoquinoline and Quinoline Derivatives 7, 8, 9 and 10

The cycloimmonium salt ( $1 \mathrm{mmol}, 1$ equiv.) and dipolarophile (fumaronitrile, $1.1 \mathrm{mmol}$, 1.1 equiv), were added to $5 \mathrm{~mL}$ dichloromethane and the obtained suspension was stirred at $\mathrm{rt}$ under $\mathrm{N}_{2}$ atmosphere. Triethylamine (TEA) ( $3 \mathrm{mmol}, 3$ equiv.) was added drop-wise over $1 \mathrm{~h}$ (magnetic stirring) and the resulting mixture was further stirred for $24 \mathrm{~h}$ at rt. Methanol $(5 \mathrm{~mL})$ was added and the resulting mixture was kept for $24 \mathrm{~h}$ without stirring. The formed precipitate was collected by filtration to give a solid which was washed with methanol. The product was crystallized from dichloromethane/methanol $(1 / 1, v / v)$.

\subsubsection{Spectral Data}

2-(2-(4-Cyanophenyl)-2-oxoethyl)isoquinolin-2-ium bromide (3c)

Brown powder; yield: $92 \%$; $\mathrm{mp} 247-249^{\circ} \mathrm{C}$; IR (KBr), $v_{\max } 3019,2977,2871,2226,1689$, $1595,1400,1230,1169,1101,990,820 \mathrm{~cm}^{-1} ;{ }^{1} \mathrm{H}-\mathrm{NMR}$ (DMSO-d $\left.d_{6}\right) \delta: 6.75(2 \mathrm{H}, \mathrm{s}, \mathrm{H}-11), 8.11$ $(1 \mathrm{H}, \mathrm{t}, J=7.5 \mathrm{~Hz}, \mathrm{H}-6), 8.18(2 \mathrm{H}, \mathrm{d}, J=8.5 \mathrm{~Hz}, \mathrm{H}-15, \mathrm{H}-17), 8.27(2 \mathrm{H}, \mathrm{d}, J=8.5 \mathrm{~Hz}, \mathrm{H}-14$, $\mathrm{H}-18), 8.33(1 \mathrm{H}, \mathrm{t}, J=7.5 \mathrm{~Hz}, \mathrm{H}-5), 8.43(1 \mathrm{H}, \mathrm{d}, J=8.0 \mathrm{~Hz}, \mathrm{H}-4), 8.56(1 \mathrm{H}, \mathrm{d}, J=8.0 \mathrm{~Hz}$, H-7), $8.72(1 \mathrm{H}, \mathrm{d}, J=7.0 \mathrm{~Hz}, \mathrm{H}-3), 8.78(1 \mathrm{H}, \mathrm{d}, J=7.0 \mathrm{~Hz}, \mathrm{H}-2), 10.09(1 \mathrm{H}, \mathrm{s}, \mathrm{H}-8) ;{ }^{13} \mathrm{C}-\mathrm{NMR}$ $\left(\mathrm{DMSO}-d_{6}\right) \delta$ : 66.3 (C-11), $116.3(\mathrm{C}-16), 118.0(\mathrm{CN}), 125.5$ (C-3), 126.8 (C-10), 127.5 (C-4), 129.0 (C-14, C-18), 130.7 (C-7), 131.5 (C-6), 133.2 (C-15, C-17), 136.3 (C-2), 136.9 (C-13), 137.3 (C-9), 137.6 (C-5), 151.7 (C-8), 190.6 (C-12); Anal. Calcd. for $\mathrm{C}_{18} \mathrm{H}_{13} \mathrm{BrN}_{2} \mathrm{O}_{2} \mathrm{C}, 61.21 ; \mathrm{H}, 3.71$; $\mathrm{N}, 7.93$. Found C, 61.2; H, 4.45; N, 7.95. 
1-(2-(4-cyanophenyl)-2-oxoethyl)quinolin-1-ium bromide $5 \mathrm{c}$

Pink powder; yield: $92 \%$; $\mathrm{mp} 264-265^{\circ} \mathrm{C}$; IR (KBr), $v_{\max } 3018,2979,2871,2228,1691$, $1595,1402,1228,1167,1103,991,823 \mathrm{~cm}^{-1},{ }^{1} \mathrm{H}-\mathrm{NMR}$ (DMSO- $\left.d_{6}\right) \delta: 7.08$ (2H, s, H-11), 8.07 $(1 \mathrm{H}, \mathrm{t}, J=8.0 \mathrm{~Hz}, \mathrm{H}-6), 8.19(2 \mathrm{H}, \mathrm{d}, J=8.5 \mathrm{~Hz}, \mathrm{H}-15, \mathrm{H}-17), 8.23(1 \mathrm{H}, \mathrm{t}, J=8.0 \mathrm{~Hz}, \mathrm{H}-7), 8.30$ $(2 \mathrm{H}, \mathrm{d}, J=8.0 \mathrm{~Hz}, \mathrm{H}-14, \mathrm{H}-18), 8.34(1 \mathrm{H}, \mathrm{dd}, J=8.5 ; 6.0 \mathrm{~Hz}, \mathrm{H}-3), 8.53(1 \mathrm{H}, \mathrm{d}, J=9.0 \mathrm{~Hz}$, $\mathrm{H}-5), 8.56(1 \mathrm{H}, \mathrm{d}, J=8.0 \mathrm{~Hz}, \mathrm{H}-8), 9.48(1 \mathrm{H}, \mathrm{d}, J=8.0 \mathrm{~Hz}, \mathrm{H}-4), 9.55(1 \mathrm{H}, \mathrm{d}, J=5.5 \mathrm{~Hz}, \mathrm{H}-2)$; ${ }^{13} \mathrm{C}-\mathrm{NMR}\left(\mathrm{DMSO}-d_{6}\right) \delta$ : 63.5 (C-11), $116.3(\mathrm{C}-16), 118.0(\mathrm{CN}), 119.3$ (C-5), $122.2(\mathrm{C}-3), 129.3$ (C-14, C-18), 129.4 (C-9), 130.0 (C-6), 130.6 (C-8), 133.0 (C-15, C-17), 136.0 (C-7), 136.9 (C-13), 138.7 (C-10), 148.8 (C-4), 151.0 (C-2), 190.4 (C-12); Anal. Calcd. for $\mathrm{C}_{18} \mathrm{H}_{13} \mathrm{BrN}_{2} \mathrm{O}_{2} \mathrm{C}$, 61.21; $\mathrm{H}, 3.71 ; \mathrm{N}, 7.93$. Found C, 61.19; H, 4.46; N, 7.96.

3-(4-Methoxybenzoyl)-1,2,3,10b-tetrahydropyrrolo[2,1-a]isoquinoline-1,2-dicarbonitrile 7a

Yellow solid; yield: $57 \%$; $\mathrm{mp} 200-202{ }^{\circ} \mathrm{C}$; IR (KBr), $v_{\max } 2950 ; 2243,1681,1628,1601$, $1315,1269,1170,1150,772 \mathrm{~cm}^{-1} ;{ }^{1} \mathrm{H}-\mathrm{NMR}$ (DMSO-d 6 ) $\delta: 3.79(1 \mathrm{H}, \mathrm{dd}, J=9.5 ; 8.0 \mathrm{~Hz}, \mathrm{H}-3)$, $3.85(1 \mathrm{H}, \mathrm{s}, \mathrm{OMe}), 4.26(1 \mathrm{H}, \mathrm{dd}, J=7.5 ; 2.5 \mathrm{~Hz}, \mathrm{H}-2), 4.32(1 \mathrm{H}, \mathrm{d}, J=9.5 \mathrm{~Hz}, \mathrm{H}-10), 5.64$ $(1 \mathrm{H}, \mathrm{d}, J=7.5 \mathrm{~Hz}, \mathrm{H}-8), 6.04(1 \mathrm{H}, \mathrm{d}, J=2.5 \mathrm{~Hz}, \mathrm{H}-1), 6.78(1 \mathrm{H}, \mathrm{d}, J=7.5 \mathrm{~Hz}, \mathrm{H}-9), 7.06-7.10$ $(3 \mathrm{H}$, overlapped signals, $\mathrm{H}-4, \mathrm{H}-16, \mathrm{H}-18)$, 7.14-7.18 (2H, overlapped signals, $\mathrm{H}-6, \mathrm{H}-7)$, $7.03(1 \mathrm{H}, \mathrm{dt}, J=7.5 ; 1.0 \mathrm{~Hz}, \mathrm{H}-5), 8.11(2 \mathrm{H}, \mathrm{d}, J=9.0 \mathrm{~Hz}, \mathrm{H}-15, \mathrm{H}-19) ;{ }^{13} \mathrm{C}-\mathrm{NMR}$ (DMSO- $d_{6}$ )

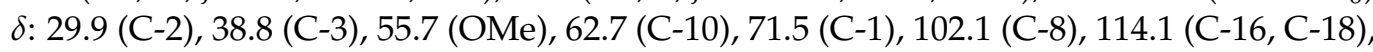
118.2 (C-21), 119.2 (C-20), 124.5 (C-4), 126.0 (C-11), 126.1 (C-6), 126.6 (C-14), 126.7 (C-7), 129.2 (C-5), 130.3 (C-12), 131.2 (C-15, C-19), 135.2 (C-9), 163.8 (C-17), 190.7 (C-13); Anal. Calcd. for $\mathrm{C}_{22} \mathrm{H}_{17} \mathrm{~N}_{3} \mathrm{O}_{2} \mathrm{C}, 74.35 ; \mathrm{H}, 4.82 ; \mathrm{N}, 11.82$. Found $\mathrm{C}, 74.36 ; \mathrm{H}, 4.80 ; \mathrm{N}, 11.85$.

3-(4-Bromobenzoyl)-1,2,3,10b-tetrahydropyrrolo[2,1-a]isoquinoline-1,2-dicarbonitrile $\mathbf{7 b}$

Yellow powder; yield: $80 \%$; $m p 207-209^{\circ} \mathrm{C}$; IR (KBr), $v_{\max } 2967 ; 2245,1695,1626,1573$, 1482, 1211, 981, $740 \mathrm{~cm}^{-1},{ }^{1} \mathrm{H}-\mathrm{NMR}$ (DMSO- $\left.d_{6}\right) \delta: 4.33(1 \mathrm{H}, \mathrm{dd}, J=7.5 ; 4.5 \mathrm{~Hz}, \mathrm{H}-3), 4.40$ $(1 \mathrm{H}, \mathrm{dd}, J=6.0 ; 4.5 \mathrm{~Hz}, \mathrm{H}-2), 5.04(1 \mathrm{H}, \mathrm{d}, J=6.5 \mathrm{~Hz}, \mathrm{H}-10), 5.38(1 \mathrm{H}, \mathrm{d}, J=7.5 \mathrm{~Hz}, \mathrm{H}-8)$, $6.00(1 \mathrm{H}, \mathrm{d}, J=8.0 \mathrm{~Hz}, \mathrm{H}-1), 6.46(1 \mathrm{H}, \mathrm{d}, J=7.5 \mathrm{~Hz}, \mathrm{H}-9), 7.00(1 \mathrm{H}, \mathrm{d}, J=7.5 \mathrm{~Hz}, \mathrm{H}-4), 7.00$ $(1 \mathrm{H}, \mathrm{t}, J=7.5 \mathrm{~Hz}, \mathrm{H}-6), 7.19-7.22(2 \mathrm{H}$, overlapped signals, $\mathrm{H}-5, \mathrm{H}-7), 7.82(2 \mathrm{H}, \mathrm{d}, J=8.0 \mathrm{~Hz}$, $\mathrm{H}-16, \mathrm{H}-18), 8.05$ (2H, d, $J=8.5 \mathrm{~Hz}, \mathrm{H}-15, \mathrm{H}-19) ;{ }^{13} \mathrm{C}-\mathrm{NMR}$ (DMSO-d $\left.\mathrm{d}_{6}\right) \delta: 32.5$ (C-2), 40.3 (C-3), 61.2 (C-10), 67.8 (C-1), 100.3 (C-8), 117.5 (C-20), 118.1 (C-21), 124.2 (C-4), 125.5 (C-11), 125.8 (C-6), 127.0 (C-7), 128.6 (C-17), 128.8 (C-5), 130.9 (C-15, C-19), 131.8 (C-12), 132.1 (C-16, C-18), 133.3 (C-14), 134.3 (C-9), 193.0 (C-13); Anal. Calcd. for $\mathrm{C}_{21} \mathrm{H}_{14} \mathrm{BrN}_{3} \mathrm{O}$ C, 62.39; $\mathrm{H}$, $3.49 ; \mathrm{N}, 10.39$. Found C, 62.41; H, 3.48; N, 10.42 .

3-(4-cyanobenzoyl)pyrrolo[2,1-a]isoquinoline-1-carbonitrile 8c

Yellow powder; yield: $65 \%$; $\mathrm{mp} 205-206^{\circ} \mathrm{C}$; IR (KBr), $v_{\max } 3149,2961,2221,1612,1450$, $1343,1260,1217,950,803 \mathrm{~cm}^{-1} ;{ }^{1} \mathrm{H}-\mathrm{NMR}\left(\mathrm{CDCl}_{3}\right) \delta: 7.39(1 \mathrm{H}, \mathrm{d}, J=7.5 \mathrm{~Hz}, \mathrm{H}-8), 7.54(1 \mathrm{H}$, s, H-2), 7.76-7.78 (2H, overlapped signals, H-5, H-6), 7.85-7.88 (3H, overlapped signals, H-16, H-18, H-7), 7.93 (2H, d, J = 8.5 Hz, H-15, H-19), 9.02 (1H, dd, J = 8.5; 3.5 Hz, H-4), $9.59(1 \mathrm{H}, \mathrm{d}, J=7.5 \mathrm{~Hz}, \mathrm{H}-9) ;{ }^{13} \mathrm{C}-\mathrm{NMR}\left(\mathrm{CDCl}_{3}\right) \delta: 86.8(\mathrm{C}-1), 115.8(\mathrm{C}-17), 116.6(\mathrm{C}-8), 116.8$ $(\mathrm{CN}), 118.1(p \mathrm{CN}), 123.6(\mathrm{C}-3), 123.9$ (C-11), 124.4 (C-4), 125.2 (C-9), 127.5 (C-7), 129.3 (C-5), 129.5 (C-2), 129.6 (C-15, C-19), 130.2 (C-12), 130.6 (C-6), 132.6 (C-16, C-18), 138.6 (C-10), 142.9 (C-14), 183.6 (C-13); Anal. Calcd. for $\mathrm{C}_{21} \mathrm{H}_{11} \mathrm{~N}_{3} \mathrm{O}$ C, 78.49; $\mathrm{H}, 3.45 ; \mathrm{N}, 13.08$. Found $\mathrm{C}$, 78.50; H, 3.42; N, 13.10 .

1-(4-methoxybenzoyl)-1,2,3,3a-tetrahydropyrrolo[1,2-a]quinoline-2,3-dicarbonitrile 9a

Yellow powder; yield: $74 \%$; $\mathrm{mp} 203-204{ }^{\circ} \mathrm{C}$; IR (KBr), $v_{\max } 2972,2852,2255,1690,1604$, 1486, 1314, 1256, 1164, $745 \mathrm{~cm}^{-1} ;{ }^{1} \mathrm{H}-\mathrm{NMR}$ (DMSO-d $\left.{ }_{6}\right) \delta: 3.91(1 \mathrm{H}, \mathrm{s}, \mathrm{OMe}), 4.21(1 \mathrm{H}, \mathrm{d}, J=$ $4.0 \mathrm{~Hz}, \mathrm{H}-3), 4.72(1 \mathrm{H}, \mathrm{d}, J=9.0 \mathrm{~Hz}, \mathrm{H}-2), 5.12(1 \mathrm{H}, \mathrm{bs}, \mathrm{H}-10), 5.74(1 \mathrm{H}, \mathrm{dd}, J=10.0,1.5 \mathrm{~Hz}$, $\mathrm{H}-4), 5.86(1 \mathrm{H}, \mathrm{d}, J=8.0 \mathrm{~Hz}, \mathrm{H}-9), 5.89(1 \mathrm{H}, \mathrm{d}, J=9.0 \mathrm{~Hz}, \mathrm{H}-1), 6.58(1 \mathrm{H}, \mathrm{t}, J=7.5 \mathrm{~Hz}, \mathrm{H}-7)$, $6.60(1 \mathrm{H}, \mathrm{d}, J=10.0 \mathrm{~Hz}, \mathrm{H}-5), 6.93(2 \mathrm{H}, \mathrm{t}, J=8.5 \mathrm{~Hz}, \mathrm{H}-8), 6.96(1 \mathrm{H}, \mathrm{d}, J=7.5 \mathrm{~Hz}, \mathrm{H}-6), 7.14$ $(2 \mathrm{H}, \mathrm{d}, J=8.5 \mathrm{~Hz}, \mathrm{H}-16, \mathrm{H}-18), 8.20(2 \mathrm{H}, \mathrm{d}, J=8.5 \mathrm{~Hz}, \mathrm{H}-15, \mathrm{H}-19) ;{ }^{13} \mathrm{C}-\mathrm{NMR}$ (DMSO- $d_{6}$ ) $\delta$ : 33.1 (C-2), 40.3 (C-3), 55.8 (OMe), 61.7 (C-10), 62.0 (C-1), 109.8 (C-9), 114.5 (C-16, C-18), 
117.1 (C-20), 117.7 (C-21), 117.8 (C-7), 119.0 (C-11), 119.6 (C-4), 127.2 (C-14), 127.4 (C-6), 128.2 (C-5), 129.6 (C-8), 131.3 (C-15, C-19), 141.0 (C-12), 164.3 (C-17), 193.0 (C-13); Anal. Calcd. for $\mathrm{C}_{22} \mathrm{H}_{17} \mathrm{~N}_{3} \mathrm{O}_{2} \mathrm{C}, 74.35 ; \mathrm{H}, 4.82 ; \mathrm{N}, 11.82$. Found $\mathrm{C}, 74.38 ; \mathrm{H}, 4.79 ; \mathrm{N}, 11.84$.

1-(4-bromobenzoyl)-1,2,3,3a-tetrahydropyrrolo[1,2-a]quinoline-2,3-dicarbonitrile 9b

Yellow powder; yield: 72\%; mp 199-201 ${ }^{\circ} \mathrm{C}$; IR (KBr), $v_{\max } 3127 ; 2215,1626,1459$, $1343,1232,973,799 \mathrm{~cm}^{-1},{ }^{1} \mathrm{H}-\mathrm{NMR}\left(\mathrm{DMSO}-d_{6}\right) \delta: 4.22(1 \mathrm{H}, \mathrm{d}, J=4.0 \mathrm{~Hz}, \mathrm{H}-3), 4.72(1 \mathrm{H}$, $\mathrm{dd}, J=9.0 ; 1.0 \mathrm{~Hz}, \mathrm{H}-2), 5.10(1 \mathrm{H}, \mathrm{t}, J=2.0 \mathrm{~Hz}, \mathrm{H}-10), 5.74(1 \mathrm{H}, \mathrm{dd}, J=10.0,2.0 \mathrm{~Hz}, \mathrm{H}-4)$, $5.90(1 \mathrm{H}, \mathrm{d}, J=8.0 \mathrm{~Hz}, \mathrm{H}-9), 5.96(1 \mathrm{H}, \mathrm{d}, J=9.0 \mathrm{~Hz}, \mathrm{H}-1), 6.58-6.63$ (2H, overlapped signals, H-7, H-5), 6.93 (1H, t, J = 8.0 Hz, H-8), $6.96(1 \mathrm{H}, \mathrm{d}, J=7.5 \mathrm{~Hz}, \mathrm{H}-6), 7.86(2 \mathrm{H}, \mathrm{d}, J=8.5 \mathrm{~Hz}$, $\mathrm{H}-16, \mathrm{H}-18), 8.17$ (2H, d, $J=8.5 \mathrm{~Hz}, \mathrm{H}-15, \mathrm{H}-19) ;{ }^{13} \mathrm{C}-\mathrm{NMR}$ (DMSO-d $) \delta: 33.1$ (C-2), 40.3 (C-3), 61.7 (C-10), 62.7 (C-1), 110.0 (C-9), 117.1 (C-20), 117.6 (C-21), 118.0 (C-7), 118.9 (C-11), 119.6 (C-4), 127.5 (C-6), 128.2 (C-5), 129.2 (C-17), 129.7 (C-8), 130.8 (C-15, C-19), 132.4 (C-16, C-18), 133.1 (C-14), 140.8 (C-12), 194.2 (C-13); Anal. Calcd. for $\mathrm{C}_{21} \mathrm{H}_{14} \mathrm{BrN}_{3} \mathrm{O} \mathrm{C}, 62.39$; $\mathrm{H}$, $3.49 ; \mathrm{N}, 10.39$. Found $\mathrm{C}, 62.40 ; \mathrm{H}, 3.48 ; \mathrm{N}, 10.41$.

2-cyano-1-(4-cyanobenzoyl)pyrrolo[1,2-a]quinoline-3-carboxamide 10c

Dark yellow powder; yield: 69\%; mp 202-204 ${ }^{\circ} \mathrm{C}$; IR (KBr), $v_{\max } 3151,2963,2222$, 1610, 1448, 1346, 1261, 1215, 952, $800 \mathrm{~cm}^{-1} ;{ }^{1} \mathrm{H}-\mathrm{NMR}$ (DMSO- $\left.d_{6}\right) \delta: 7.56(1 \mathrm{H}, \mathrm{t}, J=7.5 \mathrm{~Hz}$, H-7), $7.77(1 \mathrm{H}, \mathrm{t}, J=7.5 \mathrm{~Hz}, \mathrm{H}-8), 7.94(1 \mathrm{H}, \mathrm{d}, J=8.5 \mathrm{~Hz}, \mathrm{H}-6), 8.07(2 \mathrm{H}, \mathrm{d}, J=8.0 \mathrm{~Hz}, \mathrm{H}-16$, H-18), 8.09-8.13 (3H, overlapped signals, H-15, H-19, H-4), $8.23(1 \mathrm{H}, \mathrm{d}, J=8.5 \mathrm{~Hz}, \mathrm{H}-9)$, $8.47(1 \mathrm{H}, \mathrm{d}, J=8.5 \mathrm{~Hz}, \mathrm{H}-5), 9.00(2 \mathrm{H}, \mathrm{s}, \mathrm{NH} 2) ;{ }^{13} \mathrm{C}-\mathrm{NMR}\left(\mathrm{DMSO}-d_{6}\right) \delta: 99.8(\mathrm{C}-3), 104.1$ (C-2), $114.0(\mathrm{CN}), 114.4(p \mathrm{CN}), 116.8$ (C-4), 118.3 (C-17), 125.8 (C-11, C-1), 126.2 (C-7), 127.8 (C-6), 128.3 (C-9), 129.7 (C-15, C-19), 130.2 (C-8), 132.5 (C-16, C-18), 137.4 (C-5), 140.3 (C-14), 146.8 (C-12), 150.5 (C-10), 161.8 (CONH2), 176.4 (C-13); Anal. Calcd. for $\mathrm{C}_{22} \mathrm{H}_{12} \mathrm{~N}_{4} \mathrm{O}_{2} \mathrm{C}$, 72.52; H, 3.32; N, 15.38. Found C, 72.55; H, 3.30; N, 15.41 .

\subsection{Anticancer Activity}

The compounds were tested against a panel of 60 human cancer cell lines at the National Cancer Institute (Rockville, MD, USA). The cytotoxicity experiments were performed using a $48 \mathrm{~h}$ exposure protocol which consisted of a sulforhodamine B assay [34-36], briefly described below.

The cell lines are grown in RPMI 1640 medium containing 5\% fetal bovine serum and $2 \mathrm{mM}$ L-glutamine. For a typical screening experiment, cells are inoculated into 96 well microtiter plates in $100 \mu \mathrm{L}$ at plating densities ranging from 5000 to 40,000 cells / well, depending on the doubling time of individual cell lines. The plates are then incubated at $37^{\circ} \mathrm{C}, 5 \% \mathrm{CO}_{2}, 95 \%$ air and $100 \%$ relative humidity for $24 \mathrm{~h}$ prior to addition of compounds. After $24 \mathrm{~h}$, two plates of each cell line are fixed in situ with trichloroacetic acid (TCA), to represent a measurement of the cell population for each cell line at the time of drug addition (Tz). Compounds are solubilized in dimethyl sulfoxide at 400-fold the desired final maximum test concentration and stored frozen prior to use. At the time of drug addition, an aliquot of frozen concentrate is thawed and diluted to twice the desired final maximum test concentration with complete medium containing $50 \mu \mathrm{g} / \mathrm{mL}$ gentamicin Additional serial dilutions are made to provide a total of five drug concentrations plus control. Aliquots of $100 \mu \mathrm{L}$ of these different drug dilutions are added to the appropriate microtiter wells already containing $100 \mu \mathrm{L}$ of medium, resulting in the required final drug concentrations.

Following drug addition, the plates are incubated for an additional $48 \mathrm{~h}$ at $37{ }^{\circ} \mathrm{C}, 5 \%$ $\mathrm{CO}_{2}, 95 \%$ air, and $100 \%$ relative humidity. For adherent cells, the assay is terminated by the addition of cold TCA. Cells are fixed in situ by the gentle addition of $50 \mu \mathrm{L}$ of cold $50 \%(w / v)$ TCA (final concentration, 10\% TCA) and incubated for $60 \mathrm{~min}$ at $4{ }^{\circ} \mathrm{C}$. The supernatant is discarded, and the plates are washed five times with tap water and air dried. Sulforhodamine B (SRB) solution $(100 \mu \mathrm{L})$ at $0.4 \%(w / v)$ in $1 \%$ acetic acid is added to each well, and plates are incubated for $10 \mathrm{~min}$ at room temperature. After staining, unbound 
dye is removed by washing five times with $1 \%$ acetic acid and the plates are air dried. Bound stain is subsequently solubilized with $10 \mathrm{mM}$ trizma base, and the absorbance is read on an automated plate reader at a wavelength of $515 \mathrm{~nm}$. For suspension cells, the methodology is the same except that the assay is terminated by fixing settled cells at the bottom of the wells by gently adding $50 \mu \mathrm{L}$ of $80 \%$ TCA (final concentration, $16 \%$ TCA). Using the seven absorbance measurements [time zero, (Tz), control growth, (C), and test growth in the presence of drug at the five concentration levels (Ti)], the percentage growth is calculated at each of the drug concentrations levels. Percentage growth inhibition (PGI) is calculated as:

$(\mathrm{Ti}-\mathrm{Tz}) /(\mathrm{C}-\mathrm{Tz})] \times 100$ for concentrations for which $\mathrm{Ti}>/=\mathrm{Tz}$

$[(\mathrm{Ti}-\mathrm{Tz}) / \mathrm{Tz}] \times 100$ for concentrations for which $\mathrm{Ti}<\mathrm{Tz}$.

Three dose response parameters are calculated for each experimental agent. Growth inhibition of $50 \%\left(\mathrm{GI}_{50}\right)$ is calculated from $[(\mathrm{Ti}-\mathrm{Tz}) /(\mathrm{C}-\mathrm{Tz})] \times 100=50$, which is the drug concentration resulting in a 50\% reduction in the net protein increase (as measured by SRB staining) in control cells during the drug incubation. The drug concentration resulting in total growth inhibition (TGI) is calculated from $\mathrm{Ti}=\mathrm{Tz}$. The $\mathrm{LC}_{50}$ (concentration of drug resulting in a $50 \%$ reduction in the measured protein at the end of the drug treatment as compared to that at the beginning) indicating a net loss of cells following treatment is calculated from $[(\mathrm{Ti}-\mathrm{Tz}) / \mathrm{Tz}] \times 100=-50$. Values are calculated for each of these three parameters if the level of activity is reached; however, if the effect is not reached or is exceeded, the value for that parameter is expressed as greater or less than the maximum or minimum concentration tested.

\subsection{Tubulin Polymerization Assay}

Microtubule assembly was studied using a tubulin polymerization assay kit (Cat. \#BK006P, Cytoskeleton Inc., Denver, CO, USA) which was used according to the manufacturer's instructions [42,43]. The polymerization was monitored using a FLUOstar Omega multi-mode microplate reader (BMG LABTECH, Offenburg, Germany). The final buffer concentrations for tubulin polymerization contained $80 \mathrm{mM}$ PIPES (piperazine$N, N^{\prime}$-bis(2-ethanesulfonic acid)sequisodium salt), $\mathrm{pH}=6.9,2 \mathrm{mM} \mathrm{MgCl} 2,0.5 \mathrm{mM}$ EGTA (ethylene glycol-bis ( $\beta$-amino-ethyl ether) $N, N, N^{\prime}, N^{\prime}$-tetraacetic acid, $1 \mathrm{mM}$ GTP and 10.2\% glycerol. Test compounds were added in one single concentration $(10 \mu \mathrm{M})$ and then all compounds except the purified tubulin were warmed to $37^{\circ} \mathrm{C}$. The reaction was initiated by the addition of tubulin to a final concentration of $3.0 \mathrm{mg} / \mathrm{mL}$. Paclitaxel and phenstatin were used as positive controls under the same conditions. The absorbance was measured at $340 \mathrm{~nm}$ for $1 \mathrm{~h}$ at $1 \mathrm{~min}$ intervals at $37^{\circ} \mathrm{C}$.

\subsection{Molecular Modelling}

Molecular docking experiments were performed using a previously described protocol [18] with slight modifications. In brief, ligands were built in Avogadro v1.2.0 [44] and energetically optimized in the MMFF94 force field using the Steepest Descent algorithm until reaching a local energy minimum. Docking experiments were performed with Autodock Vina [45], using a $22 \times 22 \times 22 \AA^{3}$ gridbox centred on the colchicine binding site of the $\alpha, \beta$-tubulin heterodimer (PDB: 4O2B) [46]. The $\mathrm{x}, \mathrm{y}, \mathrm{z}$ coordinates of the center of the gridbox were $(14.316,67.184,43.659)$. Ten poses were generated for each ligand and the best scoring conformations were selected for discussion. RMSD between re-docked and co-crystallized colchicine ligand was used as quality control for the docking protocol. Visual inspection, molecular graphics and analyses were made in the PyMOL Molecular Graphics System, Version 1.8.2. (Schrödinger, LLC, New York, NY, USA) and Discovery Studio Visualizer Version 20.1.0.19295 (Dassault Systemes, BIOVIA Corp., San Diego, CA, USA).

\subsection{In Silico Prediction of Cytotoxicity}

In silico cytotoxicity for compound 9a was assessed using CLC-Pred-a web-service which provides a cytotoxicity prediction for chemical compounds in order to estimate 
the relevance of the their inclusion in experimental screening, based on their structural formula [37]. The prediction is based on Prediction of Activity Spectra for Substances (PASS; http:/ / www.way2drug.com/PASSonline) (accessed on 18 March 2021) and the training set was created based on cytotoxicity data retrieved from ChEMBLdb (https: / / www.ebi.ac.uk/chembldb/) (accessed on 18 March 2021). The list of predicted activities is arranged in descending order according to $P a-P i$ values. Thus, the most probable activities are at the top of the list. $\mathrm{Pa}$ (probability "to be active") estimates the chance that the studied compound belongs to the subclass of active compounds on that particular cell line (resembles the structures of molecules which are typically included in a subset of "actives" in the PASS training set). Pi (probability "to be inactive") estimates the chance that the studied compound belongs to the subclass of inactive compounds (resembles the structures of molecules which are typically included in a subset of "inactives" in the PASS training set).

\section{Conclusions}

The [3+2] cycloaddition of several (iso)quinolinium ylides to fumaronitrile was used for the synthesis of two series of compounds with (tetrahydro)pyrrolo[1,2-a]quinoline and (tetrahydro)pyrrolo[2,1-a]isoquinoline scaffolds, respectively. During cycloaddition, two types of products were generated, with a relative configuration of the nitrile groups identical to that observed in the parent alkene (compounds $\mathbf{7 b}, \mathbf{8 a}, \mathbf{b}$ ), as well as reversed (compound 7a). The loss of the stereo-configuration originating from the starting material in compound 7a implies an asynchronous process of formation of new $\sigma$ bonds during cycloaddition. Also, aromatization occurred in the case of compounds $8 \mathbf{c}$ and 10c, accompanied by the loss of one cyano group in the case of product $8 \mathrm{c}$ or hydrolysis of one of the cyano groups in the case of product 10c. Among the eleven compounds selected and tested against sixty human cancer cell lines at $\mathrm{NCI}$, compound $\mathbf{9 a}$ showed excellent growth inhibition, with $\mathrm{GI}_{50}$ values ranging from 0.197 to $3.49 \mu \mathrm{M}$ against 40 cancer cell lines from all nine NCI sub-panels. The anticancer properties of compound 9a could be linked to its ability to inhibit tubulin polymerization in vitro by binding the colchicine site of tubulin. The anticancer study showed that the tetrahydropyrrolo[1,2-a]quinoline scaffold appears to be more favorable in terms of potential anticancer properties when compared to its isoquinoline analogue. Further derivatization and investigation of this class of compounds are worth conducting for the development of new potential anticancer agents.

Author Contributions: Conceptualization and writing-original draft preparation were performed by R.D. and M.C.A.-M. Biological data analysis was performed by R.D., I.I.M. and R.-M.A. Synthesis and structure elucidation were performed by M.C.A.-M. and R.D. Molecular modeling experiments were performed by R.-M.A. Writing-review and editing was performed by R.-M.A. and R.D. All authors have read and agreed to the published version of the manuscript.

Funding: This work was supported by a grant of the Romanian Ministry of Education and Research, CNCS-UEFISCDI, project number PN-III-P4-ID-PCE-2020-0371, within PNCDI III. The APC was funded from the European Social Fund through the Operational Programme Human Capital 20142020, project number POCU/380/6/13/123623 “PhD students and postdoctoral researchers ready for the labor market".

Institutional Review Board Statement: Not applicable.

Informed Consent Statement: Not applicable.

Data Availability Statement: The data presented in this study are available on request from the corresponding author.

Acknowledgments: The authors acknowledge the National Cancer Institute for the anticancer evaluation of the compounds on their 60-cell panel. The testing was performed by the Developmental Therapeutics Program, Division of Cancer Treatment and Diagnosis (http:/ / dtp.cancer.gov/) (accessed on 2 March 2021). We also thank the CERNESIM Research Centre from the "Alexandru Ioan Cuza" University of Iași for performing NMR experiments. 
Conflicts of Interest: The authors declare no conflict of interest.

Sample Availability: Samples of the compounds are available from the authors.

\section{References}

1. Vitaku, E.; Smith, D.T.; Njardarson, J.T. Analysis of the Structural Diversity, Substitution Patterns, and Frequency of Nitrogen Heterocycles among U.S. FDA Approved Pharmaceuticals. J. Med. Chem. 2014, 57, 10257-10274. [CrossRef] [PubMed]

2. Zhang, S.; Zhang, J.; Gao, P.; Sun, L.; Song, Y.; Kang, D.; Liu, X.; Zhan, P. Efficient drug discovery by rational lead hybridization based on crystallographic overlay. Drug Discov. Today 2019, 24, 805-813. [CrossRef]

3. Panda, P.; Chakroborty, S. Navigating the Synthesis of Quinoline Hybrid Molecules as Promising Anticancer Agents. ChemistrySelect 2020, 5, 10187-10199. [CrossRef]

4. Abbot, V.; Sharma, P.; Dhiman, S.; Noolvi, M.N.; Patel, H.M.; Bhardwaj, V. Small hybrid heteroaromatics: Resourceful biological tools in cancer research. RSC Adv. 2017, 7, 28313-28349. [CrossRef]

5. Jain, S.; Chandra, V.; Jain, P.K.; Pathak, K.; Pathak, D.; Vaidya, A. Comprehensive review on current developments of quinolinebased anticancer agents. Arab. J. Chem. 2019, 12, 4920-4946. [CrossRef]

6. Matveeva, M.D.; Purgatorio, R.; Voskressensky, L.G.; Altomare, C.D. Pyrrolo[2,1-a]isoquinoline scaffold in drug discovery: Advances in synthesis and medicinal chemistry. Future Med. Chem. 2019, 11, 2735-2755. [CrossRef] [PubMed]

7. Pässler, U.; Knölker, H.J. The pyrrolo[2,1-a]isoquinoline alkaloids. Alkaloids Chem. Biol. 2011, 70, 79-151. [CrossRef] [PubMed]

8. Lv, H.N.; Zeng, K.W.; Zhao, M.B.; Jiang, Y.; Tu, P.F. Pyrrolo[2,1-a]isoquinoline and pyrrole alkaloids from Sinomenium acutum. J. Asian Nat. Prod. Res. 2017, 20, 195-200. [CrossRef]

9. Bailly, C. Anticancer Properties of Lamellarins. Mar. Drugs 2015, 13, 1105-1123. [CrossRef]

10. Marco, E.; Laine, W.; Tardy, C.; Lansiaux, A.; Iwao, M.; Ishibashi, F.; Bailly, C.; Gago, F. Molecular Determinants of Topoisomerase I Poisoning by Lamellarins: Comparison with Camptothecin and Structure-Activity Relationships. J. Med. Chem. 2005, 48, 37963807. [CrossRef]

11. Allin, S.M.; Gaskell, S.N.; Towler, J.M.R.; Bulman Page, P.C.; Saha, B.; McKenzie, M.J.; Martin, W.P. A New Asymmetric Synthesis of the Anti-Tumor Alkaloid (R)-(+)-Crispine A. J. Org. Chem. 2007, 72, 8972-8975. [CrossRef]

12. Tokuyama, T.; Uenoyama, K.; Brown, G.; Daly, J.W.; Witkop, B. Allenic and Acetylenic Spiropiperidine Alkaloids from the Neotropical Frog, Dendrobates histrionicus. Helv. Chim. Acta 1974, 57, 2597-2604. [CrossRef]

13. Santarem, M.; Vanucci-Bacqué, C.; Lhommet, G. Formal Total Synthesis of (+)-Gephyrotoxin. J. Org. Chem. 2008, 73, 6466-6469. [CrossRef]

14. Kemnitzer, W.; Kuemmerle, J.; Jiang, S.; Zhang, H.-Z.; Sirisoma, N.; Kasibhatla, S.; Crogan-Grundy, C.; Tseng, B.; Drewe, J.; Cai, S.X. Discovery of 1-benzoyl-3-cyanopyrrolo[1,2-a]quinolines as a new series of apoptosis inducers using a cell- and caspase-based high-throughput screening assay. Part 1: Structure-activity relationships of the 1- and 3-positions. Bioorg. Med. Chem. Lett. 2008, 18, 6259-6264. [CrossRef]

15. Kemnitzer, W.; Kuemmerle, J.; Jiang, S.; Zhang, H.-Z.; Sirisoma, N.; Kasibhatla, S.; Crogan-Grundy, C.; Tseng, B.; Drewe, J.; Cai, S.X. Discovery of 1-benzoyl-3-cyanopyrrolo[1,2-a]quinolines as a new series of apoptosis inducers using a cell- and caspase-based high-throughput screening assay. 2: Structure-activity relationships of the 4-, 5-, 6-, 7- and 8-positions. Bioorg. Med. Chem. Lett. 2009, 19, 3481-3484. [CrossRef] [PubMed]

16. Brazhko, O.A.; Yevlash, A.S.; Zavgorodnii, M.P.; Kornet, M.M.; Brazhko, O.O.; Lagron, A.V. Basic approaches to the synthesis of pyrrolo[1,2-a]quinolines derivatives: A review. Vopr. Khimii Khimicheskoi Tekhnologii 2019, 6, 6-16. [CrossRef]

17. Sardaru, M.C.; Crăciun, A.M.; Al Matarneh, C.M.; Sandu, I.A.; Amarandi, R.M.; Popovici, L.; Ciobanu, C.I.; Peptanariu, D.; Pinteala, M.; Mangalagiu, I.I.; et al. Cytotoxic substituted indolizines as new colchicine site tubulin polymerisation inhibitors. J. Enzym. Inhib. Med. Chem. 2020, 35, 1581-1595. [CrossRef] [PubMed]

18. Popovici, L.; Amarandi, R.M.; Mangalagiu, I.I.; Mangalagiu, V.; Danac, R. Synthesis, molecular modelling and anticancer evaluation of new pyrrolo[1,2-b]pyridazine and pyrrolo[2,1-a]phthalazine derivatives. J. Enzym. Inhib. Med. Chem. 2019, 34, 230-243. [CrossRef]

19. Al Matarneh, C.M.; Amarandi, R.M.; Craciun, A.M.; Mangalagiu, I.I.; Zbancioc, G.; Danac, R. Design, synthesis, molecular modelling and anticancer activities of new fused phenanthrolines. Molecules 2020, 25, 527-543. [CrossRef]

20. Danac, R.; Al Matarneh, C.M.; Shova, S.; Daniloaia, T.; Balan, M.; Mangalagiu, I.I. New indolizines with phenanthroline skeleton: Synthesis, structure, antimycobacterial and anticancer evaluation. Bioorg. Med. Chem. 2015, 23, 2318-2327. [CrossRef] [PubMed]

21. Al Matarneh, C.M.; Shova, S.; Mangalagiu, I.I.; Danac, R. Synthesis, structure and antimycobacterial properties of new pyrrolo4,7-phenanthroline derivatives. J. Enzym. Inhib. Med. Chem. 2016, 31, 470-480. [CrossRef]

22. Al Matarneh, C.M.; Ciobanu, C.; Mangalagiu, V.; Zbancioc, G.; Danac, R. Microwave Assisted Synthesis of Six Member Ring Azaheterocycles and Their Antimycobacterial and Anticancer Evaluation. Rev. Chim. 2020, 71, 287-293. [CrossRef]

23. Fatiadi, A.J. Preparation and Synthetic Applications of Cyano Compounds. In Triple-Bonded Functional Groups: Supplement C: Part 2, Volume 2; Patai, S., Rappaport, Z., Eds.; Wiley: New York, NY, USA, 1983; pp. 1057-1303. [CrossRef]

24. Al Matarneh, C.M.; Apostu, M.O.; Mangalagiu, I.I.; Danac, R. Reactions of ethyl cyanoformate with cycloimmonium salts: A direct pathway to fused or substituted azaheterocycles. Tetrahedron 2016, 72, 4230-4238. [CrossRef]

25. Al Matarneh, C.M.; Ciobanu, C.I.; Apostu, M.O.; Mangalagiu, I.I.; Danac, R. Cycloaddition versus amidation in reactions of 2-amino-2-oxoethyl phenanthroliniumylides to activated alkynes and alkenes. C. R. Chem. 2018, 21, 1-8. [CrossRef] 
26. Al Matarneh, C.M.; Isac, D.L.; Tigoianu, R.; Danac, R.; Airinei, A. Steady state and time resolved fluorescence studies of new indolizine with phenanthroline skeleton derivatives. J. Lumin. 2018, 199, 6-12. [CrossRef]

27. Al Matarneh, C.M.; Danac, R.; Leontie, L.; Tudorache, F.; Petrila, I.; Iacomi, F.; Carlescu, A.; Nedelcu, G.; Mangalagiu, I. Synthesis and electron transport properties of some new 4,7-phenanthroline derivatives in thin films. Environ. Eng. Manag. J. 2015, $14,420-431$.

28. Al Matarneh, C.M.; Ciobanu, C.I.; Mangalagiu, I.I.; Danac, R. Design, synthesis and antimycobacterial activity of some new azaheterocycles: 4,7-phenanthroline with $p$-halogeno-benzoyl skeleton. Part VI. J. Serb. Chem. Soc. 2016, 81, 133-140. [CrossRef]

29. Al Matarneh, C.M.; Sardaru, M.C.; Apostu, M.O.; Rosca, I.; Ciobanu, C.I.; Mangalagiu, I.I.; Danac, R. Synthesis and antibacterial evaluation of new pyrrolo $\left[3^{\prime}, 4^{\prime}: 3,4\right]$ pyrrolo[1,2-a]Quinoline and pyrrolo[ $\left[3^{\prime}, 4^{\prime}: 3,4\right]$ pyrrolo[2,1-a]Isoquinoline derivatives. Studia UBB Chem. 2019, 64, 67-80. [CrossRef]

30. Hopkin, M.D.; Baxendale, I.R.; Ley, S.V. A New Focused Microwave Approach to the Synthesis of Amino-Substituted Pyrroloisoquinolines and Pyrroloquinolines via a Sequential Multi-Component Coupling Process. Synthesis 2008, 11, 1688-1702. [CrossRef]

31. Jasinski, R.; Dresler, E. On the Question of Zwitterionic Intermediates in the [3+2] Cycloaddition Reactions: A Critical Review. Organics 2020, 1, 49-69. [CrossRef]

32. Mloston, G.; Urbaniak, K.; Domagała, M. Thermal [2+3]-Cycloadditions of trans-1-Methyl-2,3-diphenylaziridine with C=S and C=C Dipolarophiles: An Unexpected Course with Dimethyl Dicyanofumarate. Helv. Chim. Acta 2009, 92, 2631-2642. [CrossRef]

33. Huisgen, R.; Mloston, G.; Langhals, E. The first two-step 1,3-dipolar cycloadditions: Interception of intermediate. J. Org. Chem. 1986, 51, 4085-4087. [CrossRef]

34. Shoemaker, R.H. The NCI60 human tumour cell line anticancer drug screen. Nat. Rev. Cancer 2006, 6, 813-823. [CrossRef]

35. Skehan, P.; Storeng, R.; Scudiero, D.; Monks, A.; McMahon, J.; Vistica, D.; Warren, J.T.; Bokesh, H.; Kenney, S.; Boyd, M.R. New colorimetric cytotoxicity assay for anticancer-drug screening. J. Natl. Cancer Inst. 1990, 82, 1107-1112. [CrossRef]

36. Boyd, R.B. The NCI in vitro anticancer drug discovery screen: Concept, implementation, and operation. In Anticancer Drug Development Guide: Preclinical Screening, Clinical Trials, and Aproval; Teicher, B., Ed.; Humana Press Inc.: Totowa, NJ, USA, 1997; pp. $23-42$.

37. Lagunin, A.A.; Dubovskaja, V.I.; Rudik, A.V.; Pogodin, P.V.; Druzhilovskiy, D.S.; Gloriozova, T.A.; Filimonov, D.A.; Sastry, N.G.; Poroikov, V.V. CLC-Pred: A freely available web-service for in silico prediction of human cell line cytotoxicity for drug-like compounds. PLoS ONE 2018, 12, e0191838. [CrossRef]

38. Lu, Y.; Chen, J.; Wang, J.; Li, C.M.; Ahn, S.; Barrett, C.M.; Dalton, J.T.; Li, W.; Miller, D.D. Design, synthesis, and biological evaluation of stable colchicine binding site tubulin inhibitors as potential anticancer agents. J. Med. Chem. 2014, 57, 7355-7366. [CrossRef] [PubMed]

39. Klejborowska, G.; Urbaniak, A.; Maj, E.; Pretod, J.; Mosharie, M.; Wietrzykc, J.; Tuszynskie, J.A.; Chambers, T.C.; Huczyński, A. Synthesis, biological evaluation and molecular docking studies of new amides of 4-chlorothiocolchicine as anticancer agents. Bioorg. Chem. 2020, 97, 103664-103675. [CrossRef] [PubMed]

40. Ansari, M.; Shokrzadeh, M.; Karima, S.; Rajaei, S.; Hashemi, S.M.; Mirzaei, H.; Fallah, M.; Emami, S. Design, synthesis and biological evaluation of flexible and rigid analogs of $4 \mathrm{H}-1,2,4$-triazoles bearing 3,4,5-trimethoxyphenyl moiety as new antiproliferative agents. Bioorg. Chem. 2019, 93, 103300-103312. [CrossRef] [PubMed]

41. Onodera, K.; Satou, K.; Hirota, H. Evaluations of Molecular Docking Programs for Virtual Screening. J. Chem. Inf. Model. 2007, 47, 1609-1618. [CrossRef] [PubMed]

42. Schiff, P.B.; Fant, J.; Horwitz, S.B. Promotion of microtubule assembly in vitro by taxol. Nature 1979, 277, 665-667. [CrossRef]

43. Schofield, A.V.; Gamell, C.; Suryadinata, R.; Sarcevic, B.; Bernard, O. Tubulin polymerization promoting protein 1 (Tppp1) phosphorylation by Rho-associated coiled-coil kinase (Rock) and cyclin-dependent kinase 1 (Cdk1) inhibits microtubule dynamics to increase cell proliferation. J. Biol. Chem. 2013, 288, 7907-7917. [CrossRef]

44. Hanwell, M.D.; Curtis, D.E.; Lonie, D.C.; Vandermeersch, T.; Zurek, E.; Hutchison, G.R. Avogadro: An advanced semantic chemical editor, visualization, and analysis platform. J. Cheminform. 2012, 4, 17. [CrossRef] [PubMed]

45. Trott, O.; Olson, A.J. AutoDockVina: Improving the speed and accuracy of docking with a new scoring function, efficient optimization, and multithreading. J. Comput. Chem. 2010, 31, 455-461. [CrossRef] [PubMed]

46. Prota, A.E.; Danel, F.; Bachmann, F.; Bargsten, K.; Buey, R.M.; Pohlmann, J.; Reinelt, S.; Lane, H.; Steinmetz, M.O. The novel microtubule-destabilizing drug BAL27862 binds to the colchicine site of tubulin with distinct effects on microtubule organization. J. Mol. Biol. 2014, 426, 1848-1860. [CrossRef] [PubMed] 